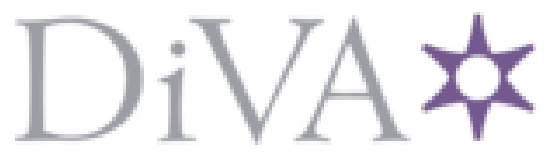

http://www.diva-portal.org

This is the published version of a paper published in Journal of world history.

Citation for the original published paper (version of record):

Eklöf Amirell, S. (2015)

Female Rule in the Indian Ocean World (1300-1900).

Journal of world history, 26(3): 443-489

https://doi.org/10.1353/jwh.2015.0023

Access to the published version may require subscription.

N.B. When citing this work, cite the original published paper.

Permanent link to this version:

http://urn.kb.se/resolve?urn=urn:nbn:se:Inu:diva-60877 


\section{PROJECT MUSE}

Female Rule in the Indian Ocean World (1300-1900)

Stefan Amirell

Journal of World History, Volume 26, Number 3, September 2015, pp. 443-489 (Article)

Published by University of Hawai'i Press

DOI: https://doi.org/10.1353/jwh.2015.0023

$\Rightarrow$ For additional information about this article https://muse.jhu.edu/article/620809 


\title{
Female Rule in the Indian Ocean World $(1300-1900)^{*}$
}

\author{
STEFAN AMIRELL \\ Lund University
}

\section{INTRODUCTION}

The Indian Ocean- here understood as the maritime and littoral zones stretching from the east coast of Africa to the Malay Archipelago of Southeast Asia-has the longest history of economic integration, intercultural contact, and communication of the world's great oceans. Maritime commerce flourished along the northern shores of the ocean well before the beginning of the Common Era, and Austronesian migrants traveled across the ocean to settle in Madagascar, probably in several waves from the middle of the first millennium c.E. to the middle of the second millennium. Long before the arrival by sea of the first Europeans at the end of the fifteenth century, the Indian Ocean trading network brought cultural and religious impulses back and forth over the ocean and along its coasts.

Many significant aspects of this great interchange have been explored by historians of the region, and the rise of global and entangled history in later years has led to a greater appreciation of the various types of similarities, contacts, and mutual influences across the ocean. ${ }^{1}$

*I thank Hans Hägerdal and Svante Norrhem for valuable comments and suggestions on the text. Research for this article was financed by a grant from the Swedish Research Council.

${ }^{1}$ There is an extensive literature on trade and other types of interaction across the Indian Ocean in the premodern era. See Kirti N. Chaudhuri, Trade and Civilisation in the Indian Ocean: An Economic History from the Rise of Islam to I 750 (Cambridge, U.K.: Cambridge University Press, 1985) for an influential synthesis, and Markus P. M. Vink, "Indian Ocean Studies and the 'New Thalassology,' Journal of Global History 2 (2007): 4I-62, for a relatively recent historiographical survey. See also Jennifer L. Gaynoer, "Ages of Sail, Ocean Basins, and Southeast Asia," Journal of World History 24 (2013): 309-33, for a recent contribution. 
One conspicuous feature, however, has hitherto not been explored systematically for the Indian Ocean World as a whole: the relatively great number of queens regnant throughout the precolonial period. Regardless of whether we turn to court chronicles, genealogies of ruling dynasties, indigenous oral traditions, or accounts by foreign observers, including Arab, Chinese, and European visitors, we find numerous references to ruling queens on the shores and islands of the Indian Ocean between the fourteenth and nineteenth century.

Several important studies of female rule in individual polities or regions around the Indian Ocean rim have been published over the last few decades, but in the context of the history of the Indian Ocean World as a whole, female rule as a general phenomenon has hitherto not been the object of any systematic study. As such, the current stateof-the-art regarding female sovereignty in the Indian Ocean World reflects the general neglect of gender in world historical scholarship, notwithstanding frequent calls for more gender analysis of global historical processes. ${ }^{2}$ The contrast is striking in comparison with the current scholarship regarding female sovereignty in Europe in medieval and early modern times, which has been explored by numerous scholars in recent decades. ${ }^{3}$

For the present study, references to 277 women rulers in the Indian Ocean World from the fourteenth to the nineteenth century have been collected from the literature and published sources (see Appendix). The list has been delimited only to women who, as far as we can tell, ruled in their own name- that is, not as, for example, regents for a minor or absent male ruler. It seems reasonable, however, to assume that more ruling queens may be found, particularly by scrutinizing unpublished material and oral sources and that moreover, there were many more of whom no records have been preserved. The 277 queens listed in the

2 E.g., Patrick Manning, Navigating World History: Historians Create a Global Past (Houndmills, Basingstoke: Palgrave Macmillan, 2003), 208-I I; Merry Wiesner-Hanks, "World History and the History of Women, Gender, and Sexuality," Journal of World History i 8 (2007): 53-67; Marnie Hughes-Warrington, "Genders," in The Oxford Handbook of World History, ed. Jerry H. Bentley, I95-209 (Oxford: Oxford University Press, 20 I I).

${ }^{3}$ For a historiographic survey, see Judith P. Zinsser and Bonnie S. Anderson, "Women in Early and Modern Europe: A Transnational Approach," in Women's History in Global Perspective, ed. Bonnie G. Smith, 3:I I I-44 (Urbana: University of Illinois Press, 2005). For some of the more important recent contributions of broader scope, see Anne J. Cruz and Mihoko Suzuki, eds., The Rule of Women in Early Modern Europe (Urbana: University of Illinois Press, 2009); William Monter, The Rise of Female Kings in Europe, 1300-1800 (New Haven, Conn.: Yale University Press, 20I 2); Theresa Earenfight, Queenship in Medieval Europe (Houndmills, Basingstoke: Palgrave Macmillan, 2013). 
appendix should thus be seen as reflecting the absolute minimum number of ruling queens in the Indian Ocean World.

It is not possible to make meaningful statistical comparisons between regions in world history with regard to the number or share of female rulers since the available figures, among other things, depend on the available source, the definition of who is a sovereign queen or ruler, and the number of states or state-like polities in each region.

A bird's eye's view of the world between I 300 and I 900 nevertheless reveals some interesting patterns. No woman, for example, seems to have exercised sovereign power over a sovereign state in the Middle East and North Africa between I 300 and I900, although a few notable women exercised considerable power as regents, for example during the so-called century of women in the seventeenth-century Ottoman Empire. ${ }^{4}$ East Asia saw only two female sovereigns-both of them figurehead Japanese emperors (tenno $)$ — during this period, although royal women occasionally were de facto influential. ${ }^{5}$ Female rule seems to have been somewhat more frequent in sub-Saharan Africa, Central Asia, and mainland South Asia, but the available sources are, with a few exceptions, scarce, as they are for pre-Columbian America.

Possibly with the exception of the sparsely populated region of Oceania (particularly Polynesia), the only region apart from the Indian Ocean World in which female rule was relatively frequent is Europe. Although there were only about thirty female sovereigns in Europe between I300 and r900-including several strong-willed and wellknown personalities such as Isabella I of Spain, Elizabeth I of England, Christina of Sweden, and Catherine II of Russia-there were, in addition, at least I 70 women who, at one time or another, ruled over more or less autonomous fiefs. ${ }^{6}$ Many of these polities were at least as advanced as the small Indian Ocean states in terms of power, size, and complexity. Historian William Monter has claimed that the period I300-1900 saw the "Rise of Female Kings in Europe," an observation

${ }^{4}$ Fatima Mernissi, The Forgotten Queens of Islam (Minneapolis: University of Minnesota Press, 2006 [1 1990]); Leslie P. Peirce, The Imperial Harem: Women and Sovereignty in the Ottoman Empire (Oxford: Oxford University Press, I 993 ).

${ }^{5}$ Joan R. Piggott, "The Last Classical Female Sovereign: Kōken-Shōtoku Tennō," in Women and Confucian Cultures in Premodern China, Korea, and Japan, ed. Dorothy Ko, JaHyun Kim Haboush, and Joan R. Piggott, 47-74 (Berkeley: University of California Press, 2003); Lien-sheng Yang, "Female Rulers in Imperial China," Harvard Journal of Asiatic Studies 23 (I96I): 47-6I.

6 Peter Truhart, Regents of Nations: Systematic Chronology of States and Their Political Representatives in Past and Present. Part 4: Volume I: Western $\mathcal{E}$ Southern Europe and Part 4: Volume 2: Eastern, Northern $\mathcal{E}$ Central Europe (Munich: K. G. Saur, 2004, 2006). 
that, together with the relatively advanced state of the historiography of female sovereignty in Europe in medieval and early modern times, provides a fruitful platform for comparison with the Indian Ocean World during the same period.

The present article investigates why female rule seems to have been relatively readily acceptable and frequent in parts of the Indian Ocean World-particularly much of maritime Southeast Asia and the east coast of Africa-in the precolonial era. The purpose is not to explain why women generally were considered unfit to rule but rather to explain why men sometimes allowed women to rule, which mainly, as far as we know, occurred in Europe and the Indian Ocean World during the period under study. Four key factors are investigated as possible explanations to the relative frequency of female rule in the Indian Ocean World: religion; trade, political stability, and gender relations. It is argued that, whereas the first and second factors fail to explain the relative frequency of female rule, the latter two-the need for political stability and the relatively non-rigid gender roles-are crucial for understanding why so many women came to the fore as rulers around the shores of the Indian Ocean in precolonial and early colonial times. The dynamics involved have obvious similarities with those of Europe during the same period, and European models of female rule may to some extent have stimulated the rise of female sovereignty in the Indian Ocean World.

\section{Methodological and Conceptual Considerations}

The meaning of the word and title "queen"-or its equivalents in other European languages, such as dronning, drottning, Königin, koningin, rainha, regina, reina, reine, and so on-is in many ways problematic. Both contemporary European sources and modern translations of non-European sources use these (or similar) titles, as does much of the literature, often uncritically. In its original, European, historical context, the title "queen" is ambiguous and denotes several rather distinct (but sometimes overlapping) functions, including that of queen consort, queen dowager, queen mother, and female vassal. ${ }^{7}$ The present investigation, however, has in principle been delimited to queens regnant (or ruling queens), that is, royal women who exercised sovereign power and reigned in their own name. As such, a queen regnant embodied, sym-

${ }^{7}$ In addition, of course, the term is used in other contexts, such as in games and zoological concepts, none of which is of interest here. 
bolically, the ultimate and highest power of the state, notwithstanding the fact that her actual power-like that of male rulers-could vary considerably. In addition, vassal queens who, as far as can be elucidated from the sources, exercised de facto sovereignty have been included in the study.

The classification, however, involves a measure of uncertainty. It is not always clear from the descriptions in the sources whether a "queen" in fact was the sovereign ruler or, for example, a queen mother acting as regent or an heiress to the throne whose political function was limited to that of transferring power to her husband. Indigenous royal titles, such as jumbe, mpanjaka, mwana, peracau, raja, rani, ratu, and sultanah, were often imprecisely defined (and frequently gender-neutral) in the vernacular, and their exact meaning depended on the context. Moreover, foreign observers, whose reports often are the most important contemporary sources, frequently misunderstood local structures of power and projected their own models on the societies they observed-for example, by uncritically denoting any political leader "king" or "queen" even though it might have been more appropriate to describe them in terms of, for example, "chieftain" or "high priest/ess."

The transfer of European concepts of state and politics in general to non-European contexts also involved assumptions about the nature of power, legitimacy, and sovereignty that were not always appropriate. Obviously, several of the "queens" mentioned in contemporary accounts did not rule over states in the European (or Chinese or Arab) sense of the word, but rather presided over quite small and often loosely organized political units that may be more properly described as tribes, chiefdoms, or port cities of varying size and importance. ${ }^{8}$ To take an extreme example, there was a huge difference in power and status between Queen Victoria of the United Kingdom, who in the mid-nineteenth century could count her subjects in hundreds of millions around the world, and her contemporary, Jumbe ("Queen") Fatimah of Mohéli in the Comoro Islands, whose modest realm comprised around five thousand people, all living on an island of a mere 230 square kilometers. ${ }^{9}$

Another problem is that the sources frequently are scarce and unevenly distributed. For many of the polities listed in the appendix there are few or no contemporary written sources; this is particularly

${ }^{8}$ E.g., Ian Caldwell, "Power, State and Society among the Pre-Islamic Bugis," Bijdragen tot de Taal-, Land- en Volkenkunde I 5 I (I995): 394-42 I; Michael N. Pearson, Port Cities and Intruders: The Swahili Coast, India, and Portugal in the Early Modern Era (Baltimore: Johns Hopkins University Press, I998), 64ff.

${ }^{9}$ Louis Langlois, "Mohély ou les mésaventures de la petite reine Fatouma," Revue de l'histoire des colonies 28 (I934): I87. 
the case for the western part of the Indian Ocean before the turn of the sixteenth century. Apart from archaeological evidence, the most important sources consist of indigenous chronicles, genealogies, oral traditions, and various notes, reports, and descriptions written by Arab, Chinese, and European visitors. A further complication is that many of the sources are biased against female political leadership. Arab and Chinese writers often found the notion of a woman exercising political power repugnant and therefore, intentionally or not, ignored or downplayed female rulers, or painted them in negative colors. ${ }^{10}$ By contrast, queens regnant were relatively common in medieval and early modern Europe, and most of the early modern European observers seem to have been relatively comfortable with and attentive to female sovereignty outside their own cultural sphere. Modern scholarship (Western as well as Middle Eastern and East Asian), on the other hand, has frequently ignored or downplayed the queens' importance-either by relegating the discussion of them to footnotes or by assuming that, because they were women, they were powerless figureheads. ${ }^{11}$

These methodological difficulties, however, should not be taken as reason to abstain from a broader study of female rule in the Indian Ocean World or from comparing the Indian Ocean World with other cultural regions with respect to the incidence of female rule. The study takes as its point of departure the many references to women exercising

10 On the bias against female leadership in the Muslim Middle East, see Mernissi, Forgotten Queens, 26, and on the negative view in imperial China, see Yang, "Female Rulers." An obvious exception is Ibn Battuta's valuable account, which in this context is of particular importance with regard to the Maldives; Muhammad Ibn Battūta, The Travels of Ibn Battututta A.D. 1325-1354, ed. H. A. R. Gibb (London: The Hakluyt Society, I994 [1355]), $822-46,865 f f$.

${ }_{11}$ E.g., Said Bakari Bin Sultani Ahmed and Lyndon Harries, The Swahili Chronicle of Ngazija (Bloomington: African Studies Program, Indiana University, I977), 84; John Middleton, The World of the Swahili: An African Mercantile Civilization (New Haven, Conn.: Yale University Press, I992), 44. See Kelly M. Askew, "Female Circles and Male Lines: Gender Dynamics along the Swahili Coast," Africa Today 46 ( I 999): 8I, 85, for a critique of the bias in modern scholarship against female political leadership, and Patricia E. Tsurumi, "The Male Present versus the Female Past: Historians and Japan's Ancient Female Emperors," Bulletin of Concerned Asian Scholars I4 (I982): 7 I-75, for a similar critique of Japanese historiography. See also Leonard Andaya, " "A Very Good-Natured but Awe-Inspiring Government': The Reign of a Successful Queen in Seventeenth Century Aceh," in Hof en handel: Aziatische vorsten en de VOC ${ }_{1} 6_{20}{ }_{1}{ }_{72} 0$, ed. Elsbeth Locher-Scholten and Peter Rietbergen, 59-84 (Leiden: KITLV Uitgeverij, 2004), although his critique of Reid's characterization of Taj al-Alam's rule seems not altogether fair. In addition, some queens, such as the Malagasy Queen Ranavalona I (I828-I86I), have been extremely, and partly unfairly, vilified; see Simon Ayache, "Esquisse pour le portrait d'une reine: Ranavalona rère," Omaly si anio I-2 (1975): 25 I-70; and Gwyn Campbell, "The Adoption of Autarky in Imperial Madagascar, I820-I 835," Journal of African History 28 ( 1987 ): 395-409, for critical assessments of such biases. 
sovereign political power-regardless of the title by which they are denoted in the sources-in the Indian Ocean World. Although the precise nature of their power and influence and the social, economic, and cultural context of the societies over which they presided varied, they are united by the fact that they embodied, symbolically, the highest political power in their person. ${ }^{12}$

\section{The Distribution of Female Rulers}

The greatest concentrations of female rulers are seen in maritime Southeast Asia, where 209 of the identified queens regnant are found, and around the East African coast (including Madagascar and the Comoro Islands), where 62 queens are known. The distribution within these two major regions, however, is very uneven, both geographically and chronologically. In Southeast Asia, South Sulawesi has, with I05 queens regnant, by far the largest number of female rulers because of the Bugis tradition of regarding women of noble descent as eligible to become leaders even when male candidates exist. Timor (East and West) also stands out statistically for its great number of female sovereigns- 63 in all - a circumstance that is largely due to the recent research efforts by historians Douglas Kammen and Hans Hägerdal. ${ }^{13}$

In the western parts of the Indian Ocean, the greatest number of female rulers are found on the Swahili coast and islands of present-day Kenya and Tanzania, where altogether 25 queens regnant are known. The Comoro Islands, moreover, saw ig female leaders and Madagascar I 6. By contrast, only a few, scattered women rulers are found on the northern shores of the Indian Ocean. In the coastal states of India, for example, only one queen regnant has been identified, and only two queens ruled in their own name over a mainland Southeast Asian state: Shinsawbu of Pegu (Burma; r. I453-1472) and Ang Mei of Cambodia (r. I 834-I840), although the latter was a powerless puppet queen. ${ }^{14}$

12 The method is inspired by the histoire croisée-approach-see Michael Werner and Bénédicte Zimmermann, "Penser l'histoire croisée: Entre empirie et réflexivité," Annales: Histoire, Sciences Sociales 58 (2003): 7-36-and comparative cross-cultural history-see Marcel Detienne, Comparer l'incomparable: Oser expérimenter et construire (Paris: Éditions du Seuil, 2000).

13 Douglas Kammen, "Queens of Timor," Archipel 84 (201 2): I 49-73; Hans Hägerdal, "Cycles of Queenship on Timor: A Response to Douglas Kammen," Archipel 85 (2013): 237-5I.

${ }_{14}$ This is certainly not due to any lack of states or historical records, of which there are a great deal from the period. 
There are chronological variations in addition to the geographic, but it is difficult to assess their significance as the sources are unevenly distributed and frequently provide only genealogies with no chronological fixed points. As expected, there is much less information about the first two centuries (before the arrival of the Europeans in the Indian Ocean) compared with later, in particular for the western part of the Indian Ocean. In general-but not in all places and regions-the sources grow increasingly abundant over time, which should, all other things being equal, be reflected in a gradual increase in the number of recorded female leaders. Such is apparently the case for the first four centuries, combined with an increase in the number of maritime polities due to the boom in trade: there are 5 recorded female rulers in the fourteenth century (that is, all or most of their regency falls between I 300 and I399), 9 in the fifteenth, 25 in the sixteenth, and 58 in the seventeenth century. ${ }^{15}$

In the eighteenth century, by contrast, the number of female rulers drops to 43 . The decline from the seventeenth to the eighteenth century may be interpreted as a corroboration of the argument, made by several students of Southeast Asia, that female rule, as well as the indigenous trading states in general, declined from the late seventeenth century mainly because of European expansion. ${ }^{16}$ In the nineteenth century, however, there are 127 known female rulers, probably due to the richer sources, although the dating of some of the queens is uncertain. In view of the great statistical uncertainty, these numbers are far from conclusive, and the regional variations are considerable.

\section{RELIGION}

As historian Barbara Watson Andaya and others have noted, the expansion of world religions in the Indian Ocean World led to a general decline in the status of women, particularly with regard to their opportuni-

15 In addition, ten rulers are undated, most of whom probably belong to the period ca. I 500-I 700; see also Askew, "Female Circles," I02 and appendix I.

${ }^{16}$ E.g., Anthony Reid, Southeast Asia in the Age of Commerce 1450-1680: Volume Two: Expansion and Crisis (New Haven, Conn.: Yale University Press, I993), 265ff.; Cheah Boon Kheng, "Power behind the Throne: The Role of Queens and Court Ladies in Malay History," Journal of the Malaysian Branch of the Royal Asiatic Society 66 (1993): 7; Stefan Amirell, "The Blessings and Perils of Female Rule: New Perspectives on the Reigning Queens of Patani, c. I 584-I 7 I 8," Journal of Southeast Asian Studies 42 (201 I): 32 I. See also Barbara Watson Andaya, The Flaming Womb: Repositioning Women in Early Modern Southeast Asia (Honolulu: University of Hawai'i Press, 2006), I69-72. 
ties to take on leading religious and ritual roles. ${ }^{17}$ It is less clear, however, to what extent the religious changes brought about by the spread of Theravada Buddhism, Islam, and Christianity entailed a decline for female political power, and the impact varied among different parts of the region and among the three religions. In general, the strongest negative impact of religious change on female political power during the period, or in the centuries preceding it, is found in mainland Southeast Asia and Sri Lanka. In both of these areas, the spread of Theravada Buddhism seems to have contributed to a decline in female royal power, and very few women ruled over a major Theravada Buddhist state in the Indian Ocean World during the period under study here, with Queen Shinsawbu providing the only significant exception. ${ }^{18}$

With regard to Christianity, the impact is less obvious. In the Philippines and Eastern Indonesia, as in Latin America, colonization and the spread of Christianity went hand in hand with Iberian expansion, but colonization, particularly toward the end of the period, appears to have been the more important process with regard to the decline in female rule. In Southeast Asia and Latin America alike, precolonial states were conquered and integrated in the Spanish and Portuguese colonial empires, which meant that to the extent that female rule had existed before the arrival of the Europeans, it disappeared with the loss of political autonomy of the indigenous states.

In Timor, however, many indigenous states survived the colonial (Dutch and Portuguese) onslaught, and around half of these were ruled at one time or another during the century by one or more women. Nearly all of the Timorese queens are denoted in the (Portuguese) sources by Portuguese names, probably indicating that they had been baptized. This "era of queens," as put by Douglas Kammen, came to an end only during the last decade of the nineteenth century as a result of the consolidation and expansion of the Portuguese colonial state on the island. The increased colonial influence brought about both a decline in political influence of indigenous states and, as observed by Hans Hägerdal, an

17 Barbara Watson Andaya and Yoneo Ishii, "Religious Developments in Southeast Asia, c. 1500-1800," in The Cambridge History of Southeast Asia, Volume One: From Early Times to c. I800, ed. Nicholas Tarling, 555-57 (Cambridge, U.K.: Cambridge University Press, I992); Barbara Watson Andaya, "The Changing Religious Role of Women in PreModern South East Asia," South East Asia Research 2 (I994): 99-I I6.

${ }_{18}$ Godfrey Eric Harvey, History of Burma (New Dehli: Asian Educational Services, 2000 [1925]), I I 7; Andaya, Flaming Womb, 75-76. See also Anthony Reid, Southeast Asia in the Age of Commerce 1450-1680: Volume One: The Land below the Winds (New Haven, Conn.: Yale University Press, I988), I69-70. 
increased orientation in politics, foreign relations, and religion toward the male rather than female sphere. ${ }^{19}$

The impact of the spread of Islam-the predominant religion in the Indian Ocean World during the period under study—on female rule is likewise ambiguous. Islam is often described as principally opposed to the idea of female leadership, in both the spiritual and political spheres. The negative view of women in politics in the Middle East is frequently justified by references to Islam, although the subordination of women in the public sphere in the region has pre-Islamic origins. ${ }^{20}$ The famous Sura 4.34 of the Qu'ran prescribes female obedience and assigns women a subordinate position to men, and later (medieval) Islamic texts, including many of the traditions (hadiths), further reinforced the inferiority of women. A tradition, written down in the ninth century, relates how Muhammad's favorite wife, A'isha, led an insurrection after the Prophet's death against the caliph and was defeated in the bloody Battle of the Camels, and her example was subsequently often cited as a warning against women in politics. The practice of female seclusion (which also has pre-Islamic origins in the Middle East), moreover, meant that women-particularly elite women, for whom seclusion was most common and strict-had few opportunities to take up political leadership positions. Most of those who nevertheless did so faced staunch opposition, particularly from religious leaders and institutions, including the caliphate. ${ }^{21}$

This bias in Middle Eastern Islam against female political leadership was a major factor that inhibited the rise of female political leaders in the region, particularly among Arabic speaking peoples, and no woman seems to have exercised sovereign political power anywhere in the Muslim Middle East during the period under study here. ${ }^{22}$ This circumstance contrasts sharply with the Indian Ocean World, where around half of the 277 identified queens seem to have been Muslims who ruled over predominantly Muslim populations. ${ }^{23}$

${ }^{19}$ Kammen, "Queens of Timor," I 5 I, I65; Hägerdal, "Cycles of Queenship," 249.

${ }^{20}$ Gerda Lerner, The Creation of Patriarchy (New York: Oxford University Press, I986).

${ }^{21}$ Mernissi, Forgotten Queens, 26, 66, passim; Nikki R. Keddie, "Women in the Middle East since the Rise of Islam," in Smith, Women's History, 7I-75.

${ }^{22}$ Mernissi, Forgotten Queens. Some women did rule as regents, however, particularly in the seventeenth-century Ottoman Empire; see Peirce, Imperial Harem.

${ }_{23}$ The estimation is based on the assumption that about two thirds of the ro5 Bugis queens (i.e., around 70) were Muslims-that is, they ruled after the Bugis conversion to Islam between I 605 and I6 I I - and the estimation that of the remaining I 7 I queens, about 67 were Muslims, based on their name, genealogy, and/or the dominant religion in the state over which they ruled. For the conversion of the Bugis to Islam, see Christian Pelras, The Bugis (Oxford: Blackwell, I996), I35-37. 
A reason for the greater frequency of ruling queens in the Indian Ocean World appears to be the prevailing influence of pre-Islamic political culture in which female rule appears to have been relatively frequent. In maritime Southeast Asia, for example, there were several ruling queens before the establishment of Islam, including at least 2 female rulers of ancient (Hindu) Java in the seventh and tenth century respectively, 6 ruling queens in Bali in the tenth and eleventh century, 2 fourteenth-century queens regnant in the Hindu realm of Majapahit (Java), and about 35 Bugis queens in South Sulawesi before early seventeenth century (that is, before the conversion of the Bugis to Islam). ${ }^{24}$ In addition, there seems to have been several queens regnant during earlier centuries in the Indianized states of mainland Southeast Asia, including Funan (second century), Champa (seventh century), and ancient Cambodia (Jayadevi, ca. 685-ca. 720). ${ }^{25}$ In Vietnam the rebel leader Trung Trac proclaimed herself queen regnant in 40 C.E. and ruled a great part of the country for three years before the rebellion was crushed by a Chinese military expedition. ${ }^{26}$ Several pre-Islamic religious ideas and myths in Southeast Asia, moreover, focus on powerful female goddesses, including that of Nyai Roro Kidul (also known as Ratu Laut Selatan, the Queen of the South Seas), a major legitimizing legend for the rulers of Yogyakarta and other Javanese sultanates. ${ }^{27}$

In contrast to the Middle East, where Islamic political models became dominant and the ruler based his legitimacy primarily on religious sanctioning, the political culture of the Muslim states in maritime Southeast Asia remained heavily influenced by pre-Islamic models of power and legitimacy. The ruler retained his or her central place in the realm, and the insignia and rituals of rulership, as well as the titles of both the ruler and the nobility, largely retained their pre-Islamic origins. After the establishment of Islam, many Southeast Asian rulers adopted Islamic titles such as sultan or shah, but in addition they frequently kept the Sanskrit raja as well as indigenous Malay titles. ${ }^{28}$ With the main exception of Aceh, few of Southeast Asia's reigning queens-most of whom are

${ }^{24}$ See the appendix for further details and references pertaining to these.

25 Trudy Jacobsen, Lost Goddesses: The Denial of Female Power in Cambodian History (Copenhagen: NIAS Press, 2008), 19, 23. The historicity of the former two is uncertain, however.

${ }^{26}$ Henri Maspero, "Études d'histoire d'Annam," Bulletin de l'École française d'ExtrêmeOrient I8 (I918): I3.

27 Judith Schlehe, Die Meereskönigin des Südens, Ratu Kidul: Geisterpolitik im javanischen Alltag (Berlin: Reimer, I998); see also Jacobsen, Lost Goddesses, I9-22.

${ }_{28}$ A. C. Milner, "Islam and the Muslim State," in Islam in South-East Asia, ed. M. B. Hooker, 29-36 (Leiden: Brill, ı983). 
found in Sulawesi-are denoted in contemporary sources with Muslim names. Although some of them (like their male counterparts) had Muslim names and titles in addition to their indigenous ones, Islam seems, for the most part, not to have played a major role in their assertions of legitimacy. Moreover, and again with the exception of Aceh, seclusion was rarely practiced by the queens nor, as far as we know, by most of their subjects. By contrast, many contemporary observers-Muslim as well as non-Muslims - noted the relaxed attitudes toward Islamic laws and prescriptions in Southeast Asia. ${ }^{29}$

The continuity in the political culture of the Southeast Asian states before and after the establishment of Islam probably also meant that the order of succession and the open attitude toward female rule, in most states, were retained. Even after the conversion to Islam in South Sulawesi in the early seventeenth century, female rule continued to be prevalent until the Dutch colonization of the region in the nineteenth century. The seventeenth century also saw two of the most remarkable instances of institutionalization of female rule in Southeast Asia (and in the world): the Malay sultanates of Patani (presently in southern Thailand), where seven female rajas reigned for most of the period between ca. I 584 and ca. I 7 I 8 , and Aceh (northern Sumatra), where four sultanahs ruled consecutively between I64I and I699. ${ }^{30}$

In the course of the early modern era, however, Southeast Asia came more into contact with the wider Muslim world, and Islamic opposition against female political leadership increased. In Aceh, where Islamic influences were particularly strong and contacts with the wider Islamic world were lively, female rule was never legitimate in the eyes of many local Islamic leaders-in spite of the attempts, particularly by the longest-serving and most successful of the four sultanahs, Taj alAlam ( $\left.164 \mathrm{I}-\mathrm{I} 6_{75}\right)$, to promote Islamic scholarship and worship and to project an image of herself as a righteous and pious Muslim ruler. ${ }^{31}$ In 1699 the last of the four consecutive Acehnese queens, Kamalat

${ }^{29}$ E.g., Milner, "Islam and the Muslim State," 27; Andaya, Flaming Womb, 88; Amirell, "Blessings and Perils," 3o8f. Note also Ibn Battūtata's failure to impose female seclusion, or even to make the women cover the upper part of their body, in the Maldives during his tenure as qadi there in the mid-fourteenth century; Ibn Batțūta, The Travels, 827 .

30 On Patani, see Amirell, "Blessings and Perils," and on Aceh, see Sher Banu A. Latiff Khan, "Rule Behind the Silk Curtain: The Sultanahs of Aceh I64I-I699," (PhD dissertation, Queen Mary, University of London, 2009).

31 Andaya, "A Very Good-Natured," 66f.; Khan, "Rule behind the Silk Curtain," I93ff. In doing so, she followed her male predecessors in the late sixteenth and early seventeenth century, all of whom sponsored Islamic scholarship, making Aceh the leading center for Malay Islamic thought at the time; see Peter G. Riddell, Islam and the Malay-Indonesian World: Transmission and Responses (London: Hurst, 2001), ro3ff. 
Sah, abdicated after her opponents had managed to secure a letter, described as a fatwa, from the Middle East declaring female leadership to be against Islam. ${ }^{32}$ In the subsequent century-at least in part because of the increasing influence of "sharia-minded" Islam in many traditional Southeast Asian states ${ }^{33}$ - female rule became increasingly rare in the region. Except for among the Bugis, few women formally took the reigns of power in any state in the region after the mid-eighteenth century. ${ }^{34}$

With regard to the western part of the Indian Ocean, there are very few written sources before the establishment of Islam. Many myths of origin that were written down in historical times do, however, feature Swahili queens as the earliest rulers. ${ }^{35}$ Regardless of their historicity, they indicate that a tradition or precedent of female rule existed in the region. In Madagascar, where Islam never was adopted by the majority of the population or their rulers, there were at least two queens regnant in the sixteenth century and five in the eighteenth century (in addition to eleven in the nineteenth century). Although evidence is scarce and further research is required, it thus seems likely that female rule along the East African coast and in Madagascar, as in Southeast Asia, drew on older, pre-Islamic models of state and power. Such political models, moreover, were probably to a significant extent transmitted from Southeast Asia to Madagascar by Austronesian immigrants. ${ }^{36}$

As in Southeast Asia, the opportunities for women to exercise sovereignty and formal political power declined in the Swahili region during the early modern period, and several students of the region have noted a generally declining status for women from the turn of the seventeenth century, in large part linked to the increasing importance of Islamic institutions such as seclusion and the adoption of Islamic laws in the region. ${ }^{37}$ However, as in maritime Southeast Asia, the Islamic

32 Khan, "Rule behind the Silk Curtain," 2 I 7; Anthony Reid, "Trade and the Problem of Royal Power in Aceh: Three States, c. I550-1 700," in idem, An Indonesian Frontier: Acehnese and Other Histories of Sumatra (Singapore: Singapore University Press, 2005), I09-10.

${ }_{33}$ Milner, "Islam and the Muslim State," 45-49.

34 Andaya, Flaming Womb, r69.

${ }^{35}$ Middleton, World of the Swahili, 42.

${ }^{36}$ E.g. Paul Ottino, "L'Ancienne succession dynastique malgache (L'exemple merina)," in Les Souverains de Madagascar: L'histoire royale et ses résurgences contemporaines, ed. Françoise Raison-Jourde, 223-63 (Paris: Karthala, I983); Gabriel Rantoandro, "Des royaumes concentriques de Java au 'Royaume de Madagascar': les fondements d'un héritage présumé," in La nation malgache au défi de l'ethnicité, ed. Françoise Raison-Jourde and Solofo Randrianja, 107-24 (Paris: Éditions Karthala, 2002).

37 Randall L. Pouwels, Horn and Crescent: Cultural Change and Traditional Islam on the East African Coast, 800-1900 (Cambridge, U.K.: Cambridge University Press, 1987), 28; Askew, "Female Circles," 92; Iris Berger and E. Frances White, Women in Sub-Saharan Africa (Bloomington: Indiana University Press, I999), 2 I. 
influences were in part balanced by the emphasis on mila (custom) in the Swahili region, which accorded women higher status in the social, political, economic, and ritual spheres. ${ }^{38}$

Similarly, several women wielded supreme power in the Comoro Islands throughout the period of European contact. The Sultanates of Anjouan, Bajini, Hamahame, Hambuu, Itsandra, Mayotte, M'Budi, and Mohéli were each ruled by at least one woman between the mid-sixteenth and late nineteenth century, and altogether the names of nineteen female rulers of the Comoro Islands have been preserved. As in much of Southeast Asia the observance of Islam appears to have been relatively relaxed in the Comoro Islands, particularly with regard to the position of women. Women generally enjoyed high status in the social and economic spheres, seclusion was rare among non-Arab women, and everyday social interaction between the sexes seems to have been relatively relaxed and uncumbered by religious regulations. ${ }^{39}$

In contrast to most of Southeast Asia, the majority of female rulers in the Comoro Islands are recorded by Muslim names such as Alimah/Halima, Aisa, and Fatima. The name practice probably reflects the greater Arabic influence in the Comoros (and along the East African coast in general), but may also indicate, from the perspective of the genealogies and chronicles that have been preserved, that the Comorese female rulers based their legitimacy on Islam to a greater extent than their Southeast Asian counterparts.

\section{Trading Queens or Warrior Queens?}

The historian Antony Reid has argued for a link between the mercantile orientation of the city states in Southeast Asia and the relative frequency of female rule in the region during its "Age of Commerce," from the early fifteenth century to the late seventeenth century. In addition to Patani and Aceh, Reid mentions Pegu, Banten, Jambi, Japara, Solor, Sukadena, and Kelantan, all of which were ruled by one or several

38 Askew, "Female Circles," 74f.; Pat Caplan, "Gender, Ideology and Modes of Production on the Coast of East Africa," Paideuma 28 (1982): 29-43.

${ }^{39}$ Martin Ottenheimer and Harriet Ottenheimer, Historical Dictionary of the Comoro Islands (Metuchen, N.J.: Scarecrow, I994), 90; Anne Molet-Sauvaget, ed., Documents anciens sur les îles Comores (I59I-I8IO) (Paris: Institut des langues et civilisations orientales, I994), 43; Jean-Louis Guébourg, La Grande Comoro des sultans aux mercenaires (Paris: l'Harmattan, I993), 30. Evidence from the seventeenth and early eighteenth century is somewhat contradictory, however, and indicates cautiousness on the part of Comorese women in their relations with Europeans; see Molet-Sauvaget, Document anciens, 43, 67, 68. 
women at various times between the fifteenth and seventeenth centuries. Female rule often coincided with periods of commercial expansion, economic prosperity, and relatively peaceful conditions for the states in question. In giving their support for a woman on the throne, the citystates' influential merchant-aristocrats (orangkaya) opted, in Reid's words, "not only for mild rule but for businesslike rule." Female rule was allegedly also promoted by the widely attributed skills of women in Southeast Asia in matters of trade and negotiation. Whereas men, according to Reid, were expected to give priority to matters of status and honor on the battlefield and to be profligate with their wealth, it "was women's business to understand market forces, to drive hard bargains, and to conserve their capital. In general, these expectations of women as rulers were not disappointed." 40 Several authors have followed Reid's argument, which thus seems to have become a widely accepted explanation for the relative frequency of female sovereignty in Southeast Asia and possibly beyond. ${ }^{41}$

The ascription of commercial skills to women (historically as well as today) are found not only in Southeast Asia, but also in the Comoro Islands and on the Swahili Coast, where women in precolonial times often had prominent roles as, for example, traders, lenders of money, and property owners. ${ }^{42}$ Since many women in the western parts of the Indian Ocean, just as in Southeast Asia, ruled over prosperous tradingstates, including Itsandra, Mombasa, Pate, Pemba, and Zanzibar, Reid's argument seems like a reasonable hypothesis for explaining the prevalence of female rule not only in Southeast Asia but also in the Indian Ocean World more broadly. ${ }^{43}$

A problem with the proposition, however, is that women in both the eastern and western parts of the Indian Ocean were prominent mainly in

${ }^{40}$ Reid, Southeast Asia, I:I 70-72. The argument was initially put forward in Anthony Reid, "Trade and State Power in the I6th \& I 7th Century Southeast Asia," in Proceedings: Seventh IAHA Conference, Bangkok, 22-26 August 1977, I:408-I2 (Bangkok: Chulalongkorn University Press, I979). The argument was extended in a short text aimed at a wider audience: Antony Reid, "Charismatic Queens of Southern Asia," History Today 53, no. 6 (2003): 30-35.

${ }_{41}$ Francis R. Bradley, "Piracy, Smuggling, and Trade in the Rise of Patani, I 490-160o," Journal of the Siam Society 96 (2008): 45, for example, makes the same proposition with regard to the enthronement of Patani's first reigning queen around I 584. See also Amirell, "Blessings and Perils," 32 If.; Cheah Boon Kheng, "Power behind the Throne." Khan, "Rule behind the Silk Curtain," 8-9, questions this explanation, however.

42 E.g., Ottenheimer and Ottenheimer, Historical Dictionary, 90; Pouwels, Horn and Crescent, 28; Margaret Strobel, Muslim Women in Mombasa 1890-1975 (New Haven, Conn.: Yale University Press, I979), I35ff.

${ }^{43}$ See Reid, "Charismatic Queens," where he extends the argument to South Asia (but not to Africa). 
petty, local trade, whereas long-distance trade to a much greater extent was in the hands of men. Although some elite women, including members of royal families, engaged in commercial activities, long-distance trade was by and large male-dominated. ${ }^{44}$ In the Swahili region-but also in parts of Southeast Asia, such as Aceh-the trading activities and interaction of women with male traders was rendered difficult by the practice of seclusion, which was most strictly enforced precisely among those elite women who possessed the economic and political means to engage in such trade. Moreover, for a city-state to have a female ruler was probably not an advantage when it came to dealing with foreign merchants or heads of state, including Arabs, Persians, Indians, and Chinese, many of whom regarded female rule as an unacceptable anomaly. ${ }^{45}$

The argument for a link between female rule and commercial orientation has its strongest support in the contemporary (European) sources for Patani, where female rule was not only adopted as temporary solution but institutionalized for most of the period from the late sixteenth to the early eighteenth century. At least the first two queens, Raja Ijau (r. I 584-I6r6) and Raja Biru (r. I6I6-ca.r624) oversaw generally open, peaceful, and commercially oriented policies that, paired with relative political stability, contributed significantly to Patani's commercial expansion and general economic prosperity. Europeans who visited the city-state to trade in the early seventeenth century described Patani's business climate in positive terms and observed how Raja Ijau personally was involved in trade and trade-promoting activities. According to the Dutch Admiral Jacob van Neck, who visited Patani at the height of the Raja Ijau's reign, she "has reigned very peaceably with her councillors ... so that all the subjects consider her government better than that of the dead king. For all necessities are very cheap here now, whereas in the king's time (so they say) they were dearer by half, because of the great exactions which then occurred." 46 During Raja Ijau's reign, moreover, both the Dutch and the English were granted permission to set up

${ }^{44}$ Andaya, Flaming Womb, I24, I87; Reid, Southeast Asia, I:I63-65. See also Khan, "Rule behind the Silk Curtain," 54f., for a rebuttal of Reid's argument with regard to the enthronement of Taj al-Alam.

45 Such sentiments were, for example, expressed by Chinese merchants about Patani in the end of the seventeenth century; Yoneo Ishii, ed., The Junk Trade from Southeast Asia: Translations from the Tôsen Fusetsu-gaki, I674-1723 (Singapore: Institute of Southeast Asian Studies, I998), I05, II3.

${ }^{46}$ Quoted and translated by Reid, Southeast Asia, I I 7I. For the Dutch original, see Jacob van Neck, "Journaal van Jacob van Neck" [1604], in De Vierde schipvaart der Nederlanders naar Oost-Indië onder Jacob Wilkens en Jacob van Neck (I599-I604), ed. Jhr. H. A. van Foreest and A. de Booy ('s-Gravenhage: Martinus Nijhoff, I980), I:226. 
trading factories in Patani, and the queen was personally involved in trade and money lending. 47

The open and commercially oriented policies of Raja Ijau thus contributed to Patani's flourishing in the first decades of the seventeenth century. Similarly, the first and longest-serving of Aceh's four sultanahs, Taj al-Alam, a few decades later, also welcomed European and other traders and promoted Aceh's rise as an important entrepôt in the region. The country prospered as a center for the export of pepper, gold, and tin, in part because of the sultanah's and the leading nobility's policies aimed at providing security for private goods and property and at maintaining largely peaceful conditions. ${ }^{48}$

Particularly in contrast to the despotism and tyranny of her father, Iskandar Muda (r. I607-I636), the rule of Taj al-Alam stands out for its benevolence and deliberative character, and female rule was later in the seventeenth century motivated as a safeguard against such absolutist excesses. ${ }^{49}$ Similar policies seem to have continued throughout the seventeenth century until the eventual demise of female rule in Aceh in I699. ${ }^{50}$ However, as the recent studies by Amirell and Khan (on Patani and Aceh respectively) have shown, there is nothing in the contemporary sources that indicate that female rule was adopted for the purpose of promoting trade or trade-friendly policies. ${ }^{51}$

Beyond Southeast Asia, a few more examples of commercially oriented rulers can be found among the 277 queens regnant in the Indian Ocean World from the fourteenth to the nineteenth century. Ibn Battūta first-hand account of the Maldives under Khadija (ca.I348-1379)

${ }^{47}$ H. Terpstra, De factorij der Oostindische Compagnie te Patani ('s-Gravenhage: Martinus Nijhoff, 1938), 9; John Anderson, English Intercourse with Siam in the Seventeenth Century (London: Kegan Paul, Trench, Trübner \& Co., r 89o), 48, 6r. See further Amirell, "Blessings and Perils," 3 I I, and therein cited references, for Raja Ijau's trade-friendly policies.

48 See Reid, "Trade and State Power," 4Io, for several contemporary reports to that effect; see also Sher Banu A. L. Khan, "The Sultanahs of Aceh, I64I-99," in Aceh: History, Politics and Culture, Arndt Graf, Susanne Schroter, and Edwin Wieringa, eds. (Singapore: Institute of Southeast Asian Studies, 2010), I 5-18.

49 According to Thomas Bowrey, A Geographical Account of Countries round the Bay of Bengal, [a.r688], ed. R. C. Temple (Cambridge, U.K.: The Hakluyt Society, I905), 298, the sultanah was put on the throne by the "wisest men" of the country in an attempt to fortify themselves "against all Kingly Government." See also Reid, "Trade and State Power," 4 Io. A similar reason for the institutionalization of female rule in Patani was given by Nicholas Gervaise, Histoire naturelle et politique du Royaume de Siam (Paris: Claude Barbin, I688), 3 I6, although as a contemporary source in this context he is of limited value, because he wrote his account more than a century after Raja Ijau's accession to the throne and probably had no first-hand experience of Patani. See moreover Amirell, "Blessings and Perils," 3 I gf., for a critique of the value of Gervaise's account as a source for Patani's history.

50 Andaya, "A Very Good-Natured," 75; Khan, "Rule behind the Silk Curtain," I 88-89.

51 Amirell, "Blessings and Perils," 305-8; Khan, "Rule behind the Silk Curtain," 54-55. 
gives the impression of a trade-oriented society accustomed to welcome foreign visitors and entertaining lively commercial relations with India, China, and Yemen. The sultanah herself, however, apparently wielded little actual power, and state affairs were in the hands of her husband and principal minister, the Wazir. ${ }^{52}$ Wabedja, the first female ruler of the small sultanate of Itsandra on Ngazidja (Great Comoros) in the first half of the eighteenth century, actively encouraged economic development, including commercial activities, but in doing so, she merely continued the policies that had been initiated by her son and predecessor, Djumwamba. ${ }^{53}$

Against these scattered examples of supposedly peaceful trading queens, at least as many examples of "warrior queens" (to borrow Antonia Fraser's term) from the Indian Ocean World can be brought forward.$^{54}$ Particularly in Southeast Asia, women's active participation in war and military affairs more generally seems to have been readily accepted and relatively common, although, women do not, as a general rule, seem to have taken part in offensive combat. ${ }^{55}$ Royal women, nonetheless, frequently took on leading roles in military affairs, and in the sources war seems to be associated with female rule in the Indian Ocean World at least as much as trade. Queen Kalinyamat (ca.I549I 579) of Jepara, for example, is more strongly remembered for her naval expeditions and attack on Portuguese Malacca than for presiding over Jepara's commercial expansion. ${ }^{56}$

${ }^{52}$ Ibn Battūtạ, The Travels, 826f., 833 .

53 B. A. Damir, G. Boulinier, and P. Ottino, Traditions d'une lingée royales des Comores (Paris: l'Harmattan, 1985), 57.

${ }^{54}$ Antonia Fraser, The Warrior Queens: Boadicea's Chariot (London: Orion, 2002 [I988]).

${ }^{55}$ For examples of female participation in military affairs in early modern Southeast Asia, see Reid, Southeast Asia, I:I66-68; Andaya, Flaming Womb, i 70. For the colonial period, see Carmen A. Abubakar, "Wither the Roses of Yesteryears: An Exploratory Look into the Lives of Moro Women during the Colonial Period," Review of Women's Studies 8 (2012): I $24-25$.

56 Chusnul Hayati, Agustinus Supriyono, Sugiyarto, Siti Maziyah, Mulyo Hadi Purnomo, and Alamsyah, Ratu Kalinyamat: Biografi tokoh wanita abad XVI dari Jepara (Semarang: Penerbit Jeda, 2007). See also John Crawfurd, History of the Indian Archipelago: Containing an account of the manners, arts, languages, religions, institutions, and commerce of its inhabitants (Edinburgh: Archibald Constable etc., I 820), I:74f., for a contemporary description of the queen of Lipukasi in South Sulawesi enticing her warriors to battle; and John Gray, History of Zanzibar: From the Middle Ages to I 856 (London: Oxford University Press, I962), 52-54, for the military aid provided to the Portuguese against Oman by Queen Fatuma of Zanzibar. Ibn Battūta, The Travels, 884-87, allegedly visited the court of a warrior princess named Urduja of whom he gave a vivid (but disputed) account. The location of her court (in Kailukari, Tawalisi) has not been identified, but if she was a historical figure, her capital almost certainly was located in Southeast Asia, probably Indochina or the Philippines; see Thomas Suárez, Early Mapping of Southeast Asia: The Epic Story of Seafarers, Adventurers, and Cartographers Who First Mapped the Regions between China and India (Hong Kong: Periplus, 1999), I05. 
Other female rulers-among them a couple of the most powerful and colorful ones - were unambiguously oriented toward war, and their strongfisted rule constituted anything but peaceful, open, or trade friendly policies. In Patani, Raja Ijau's younger sister Raja Ungu (r. ca. I624-I635) was an absolutist ruler whose bellicose foreign policy was guided by her strong antipathy for the country's mighty neighbor Siam. Her militarism and unyielding foreign policy ran counter to the commercial interests of both the city's merchant-aristocrats and the Dutch East India Company, and the latter tried in vain to mediate and to prevent the queen from going to war with Siam. ${ }^{57}$ Another example comes from Madagascar (Imerina) two centuries later, where Queen Ranavalona I ( I828-I86I) discontinued the open and commercially oriented policies of her predecessor and husband, Radama I, by restricting trade, expelling most Europeans, and persecuting Christians. Her reign was marked by a great destruction of human lives and social and economic upheaval. ${ }^{58}$

Aside from these and a few other isolated examples of strong female rulers, however, most reigning queens of the Indian Ocean World between the fourteenth and nineteenth century seem to have exercised relatively little real power. The majority of the female rulers whose names and approximate reigns have been preserved in the sources have left little further trace of their context, character, and policies. In this respect, however, they do not differ from most of their male counterparts during the Age of Commerce in Southeast Asia and much of the wider Indian Ocean World. The typical ruler, both in the maritime Southeast Asian city-states and their counterparts on the Swahili Coast and in the Comoro Islands, was a primus inter pares-a merchant-prince(ss) whose first duty was to represent the state vis-à-vis other states and whose power mainly depended on personal wealth, which generally was derived from a combination of land ownership, royal monopolies, taxation, and trade..$^{59}$ In this respect, there was little difference between a male and female ruler, and the legitimacy - at least in the Weberian legal-rational sense- of most rulers depended above all on their ability to deliver stability and favorable conditions for trade and thus prosperity. Given that there are plenty of examples throughout the Indian Ocean World of male rulers who promoted trade-friendly policies and,

57 Amirell, "Blessings and Perils," 31 5, and therein cited contemporary sources.

${ }^{58}$ Hubert Deschamps, Histoire de Madagascar (Paris: Éditions Berger-Levrault, I972), I 52-53, I 59-6I, I64-67; see also Ayache, "Esquisse pour le portrait"; Campbell, "Adoption of Autarky."

59 Middleton, World of the Swahili, 44. Middleton, like Harries, in Ahmed and Harries, Swahili Chronicle, 84 , is dismissive, however, of the possibility of women exercising real political power at all, although the question is not explored in depth. 
conversely, plenty of examples of female rulers who engaged in war and generally aggressive foreign policy - and since no contemporary sources explicitly states that female rule would have been adopted for commercial reasons - the proposition of a link between female rule and commercial orientation must be regarded as tangential rather than causal.

\section{Peace and Political Stability}

Female rule is sometimes-particularly from idealistic, maternalist perspectives but also in some traditional Southeast Asian cultures, such as among the Minangkabau — linked to peace and accommodation..$^{60}$ Even though there are numerous historical examples of women who have more or less successfully led their countries in war-a few of them even physically, on the battlefield - the argument is relevant both in terms of prescribed gender roles and because historically a major task of the sovereign has been that of war leader. As such, due to physical, cultural, and possibly sociobiological differences between men and women, men have often been regarded as more qualified political leaders. A major reason why the overwhelming majority of heads of state throughout history have been men thus seems to be due to the fact that women generally have been regarded as less capable than men in military matters. ${ }^{61}$

In early modern Europe, the perceived military weakness of a country governed by a woman was advanced as a major argument against female rule during the so-called Querelle des Femmes in the sixteenth and seventeenth centuries. ${ }^{62}$ Similar perceptions seem to have been dominant in Southeast Asia and possibly the wider Indian Ocean World. For example, in Patani, the decline of royal power during the last of the four reigning queens of the so-called Inland dynasty around the mid-seventeenth

${ }^{60}$ E.g., Marija Gimbutas, The Civilization of the Goddess: The World of Old Europe (San Francisco: HarperSanFrancisco, I99I); Francis Fukuyama, "Women and the Evolution of World Politcs," Foreign Affairs 77, no. 5 (1998): 24-40; Peggy Reeves Sanday, Women at the Center: Life in a Modern Matriarchy (Ithaca, N.Y.: Cornell University Press, 2002), 45. See also Jean Bethke Elshtain, Women and War (Chicago: University of Chicago Press, I995); Fraser, Warrior Queens.

${ }_{61}^{6}$ Marvin Harris, Our Kind (New York: HarperCollins, 1989), 284-93; see also Eileen McDonagh, The Motherless State: Women's Political Leadership and American Democracy (Chicago: University of Chicago Press, 2009), 7.

${ }^{62}$ Jean Bodin, Les Six livres de la république (Paris: Iacquees du Puys, I583), Ioo6-13. For the European context, see further Paula Louise Scalingi, "The Scepter or the Distaff: The Question of Female Sovereignty, I5 I6-I607," Historian 4I (I978): 59-75; Joan Kelly, "Early Feminist Theory and the 'Querelle des Femmes,' I 400-I 789," Signs: Journal of Women in Culture and Society 8 (1992): 4-28; Sharon L. Jansen, The Monstrous Regiment of Women: Female Rulers in Early Modern Europe (New York: Palgrave Macmillan, 2010 [2002]). 
century was related to foreign incursions (from Johor and Aceh) backed by violence and threats of violence. ${ }^{63}$ Toward the end of the century, moreover, when Patani was but a shadow of its former glory, partly as a consequence of Siamese invasions in I674 and I688, a Chinese visitor observed that "Patani is a country ruled by a Queen and not a country of military prowess." ${ }^{64}$ Even among the Bugis of Sulawesi, who were unique in accepting that women of noble descent could become sovereigns wielding real power in their own name even when there were eligible male candidates, women seem to have been disadvantaged because of their generally weaker military skills. ${ }^{65}$ From this perspective, it seems unlikely that female rule would have been preferred as a means of securing peaceful foreign relations, and no contemporary arguments to that effect seem to have been preserved.

Domestically, however, and in the absence of a legitimate male heir, female succession was useful as a way to preserve dynastic stability and avoid or end dynastic infighting and civil war. Such was the case in Patani at the time of Raja Ijau's accession to the throne around I 584 . According to the Hikayat Patani, her reign followed upon a period of political instability and dynastic infighting, which had left all the male heirs to the throne dead. The city's nobility then elected Raja Ijau, the eldest daughter of a former king, as queen regnant. That female rule was institutionalized in the first half of the seventeenth century, moreover, seems to have been due to the absence of male heirs. All three subsequent successions (in I6 16, I624, and I635) to other female members of the dynasty also appear to have been uncontested. ${ }^{66}$

In Aceh, the institutionalization of female rule originated with Taj al-Alam's accession to the throne in I64I. According to a contemporary first-hand witness, however, Taj al-Alam was originally proclaimed "regent" (Regente) rather than sultanah or ruler in her own right, ${ }^{67}$ a circumstance that indicates that her reign initially was regarded as a temporary solution. Her accession followed the advice of the most

63 Amirell, "Blessings and Perils," 3 I 7 f.

${ }^{64}$ Ishii, Junk Trade, 6o; compare Reid, Southeast Asia, 2:266.

${ }^{65}$ Caldwell, "Power, State and Society," 408; see also F. David Bulbeck, "The Politics of Marrriage and the Marriage of Polities in Gowa, South Sula Wesi, during the r6th and I 7 th Centuries," in Origins, Ancestry and Alliance: Explorations in Austronesian Ethnography, ed. James J. Fox and Clifford Sather, 283-3 I 7 (Canberra: Australian National University, 2006), http://www.oapen.org/download?type $=$ document\&docid $=459399$.

${ }^{66}$ Amirell, "Blessings and Perils," 306f. In Aceh, by contrast, the successions in I675, I 678 , and I 688 were all contested by male claimants to the throne.

${ }^{67}$ Nicolaus de Graaff, Reisen van Nicolaus de Graaff na de vier gedeeltens des Werelds, als Asia, Afica, America en Europa (Amsterdam: tot Hoorn, I 701 ), 9; de Graaff was in Aceh at the time and wrote his account shortly afterwards. 
influential Malay mirror of princes at the time, Taj us-Salatin ("The Crown of Kings," I603): Women, according to the manual, were in principle unfit to rule because of their tendency to make decisions based on emotions rather than rational consideration. In extraordinary circumstances, however, women could be allowed to ascend the throne when no male heir was available in order to prevent internal chaos. ${ }^{68}$ Moreover, the circumstance that female rule, as far as we know, was not institutionalized in any other Southeast Asian trading city-state indicates that it was generally seen as an extraordinary measure aimed at preserving dynastic order of succession and political stability.

Antony Reid has suggested that Aceh "presumably" was inspired by Patani in adopting female rule, although he does not advance any concrete evidence or indication in support of the presumption. ${ }^{69}$ Contemporary sources rather indicate that England under Elizabeth I ( $558-1603$ ) was the main inspiration for Aceh. The Acehnese rulers and other notables appear to have been well informed about European politics, particularly the actions of the English queen. The English envoy James Lancaster, who visited Aceh in I602, reported that he spoke at length to Acehnese notables about Queen Elizabeth's benevolent rule and England's victory over Spain and that they were very interested. ${ }^{70}$ Against that background, it may be no coincidence that the Taj us-Salatin, which was composed in Aceh around the same time, seems to echo some of the arguments for and against female rule that were voiced in Europe during the Querelle des Femmes. The explicit laws designed to preclude Taj al-Alam from marrying or coming under the control of any man, moreover, show resemblance to the European discussions about the problems of female rule in the preceding century. ${ }^{71}$

Another indication that European models of female monarchy may have been of some significance is the report by an English visitor to the Comoro Islands, John Pike, in the beginning of the eighteenth century. He was told that the elevation of Alimah III to the throne of Anjouan was inspired by an English example (Queen Anne). ${ }^{72}$ Pike himself, however, did not believe that this was the actual reason, and his skepticism

${ }^{68}$ Bukhārī, Taj Us-Salatin, [r6o3], ed. Khalid M. Hussain (Kuala Lumpur: Dewan Bahasa dan Pustaka, I992), 60.

${ }^{69}$ Reid, "Charismatic Queens," 33.

70 James Lancaster, The Voyages of Sir James Lancaster to Brazil and the East Indies, I59 II603, [r603], ed. Sir William Foster, (London: the Hakluyt Society, I940), 96ff.; see also William Marsden, The History of Sumatra: A Reprint of the Third Edition: Introduced by John Bastin [I 8I I] (Oxford: Oxford University Press, I986), 448.

${ }^{71}$ Bowrey, Geographical Account, 298f.

72 Mollet-Sauvaget, Documents anciens, 67 . 
should perhaps caution us not to give undue importance to possible transnational influences between Europe and the Indian Ocean World. As the Dutch orientalist Pieter Johannes Veth pointed out in relation to Aceh already in 1870 , it is wrong to assume that female rule was something new and previously unheard of in seventeenth century Southeast Asia: It was, in fact, a relatively common and well-established practice throughout the Malay world well before the arrival of the Europeans in the Indian Ocean. ${ }^{73}$

The need to preserve dynastic stability thus appears to have been a major motive for female rule in the Indian Ocean World. In that sense, the dynamics of gender and royal succession resemble their European counterpart, and indeed the pragmatic arguments for and against female rule bear striking resemblance to those advanced in Europe in the sixteenth and seventeenth centuries. Particularly in the case of Aceh, European influences may have played a role, but in general, the occasional adoption of female rule in both Europe and the Indian Ocean World between the fourteenth and nineteenth centuries seems to have been conditioned more by similarities in political and kinship systems than by the transfer of political ideas from one region to another. There are also indications that European advances in the political, diplomatic, and religious spheres, particularly after the turn of the eighteenth century, to some extent discouraged female rule in parts of maritime Southeast Asia (and possibly beyond). ${ }^{74}$

\section{Matrifocality and Female Rule}

In spite of great cultural variations, a common denominator of most societies of the Indian Ocean World where ruling queens are found is their matrifocal orientation. ${ }^{75}$ The exact definition of the term "matrifocal" has been the subject of much discussion since it first was coined in the I950s, but for the present purposes it will be used in the sense proposed by anthropologist Nancy Tanner. In her comparative study of Asian, African, and Afro-American societies, she defined matrifocality

${ }^{73}$ P. J. Veth, "Vrouwenregeeringen in den indischen archipel," Tijdschrift voor Nederlandsch-Indië 4 ( I 870): 366.

${ }^{74}$ E.g., Andaya, Flaming Womb, I69; Hägerdal, "Cycles of Queenship," 249.

75 E.g., George Coèdes, The Indianized States of Southeast Asia (Honolulu: University of Hawai'i Press, I968 [1963]), 8-9; Reid, "Charismatic Queens"; Ottino, "L'Ancienne succession," 257; Jocelyn Linnekin, Sacred Queens and Women of Consequence: Rank, Gender, and Colonialism in the Hawaiian Islands (Ann Arbor: University of Michigan Press, I990). On Polynesia, see also Niel Gunson, 'Sacred Women Chiefs and Female 'Headmen' in Polynesian History," Journal of Pacific History 22 ( 1987 ): 139-72; Andaya, Flaming Womb, $38 \mathrm{f}$. 
in terms of two constructs: "( 1 ) kinship systems in which (a) the role of the mother is structurally, culturally, and affectively central and (b) this multidimensional centrality is legitimate; and (2) the societies in which these features coexist, where (a) the relationship between the sexes is relatively egalitarian and (b) both women and men are important actors in the economic and ritual spheres." 76

In most of the societies under study here, kinship was traced either matrilineally or bilaterally. This was the case among most Austronesian groups of maritime Southeast Asia, as well as in the wider Austronesian world, including Polynesia and Madagascar. Both in the Swahili region and in the Comoro Islands, moreover, pre-Islamic systems of kinship were probably matrilineal, and traces of this are still visible in parts of the region even today. ${ }^{77}$ The Minangkabau of Sumatra also trace kinship matrilineally, and women play important roles in all spheres of public life. Even though no example of a historical reigning queen is known from the Kingdom of Minangkabau, the legend of Puteri (Princess) Jamilan - a title attributed to a line of legendary but highly revered queen mothers-indicates that female political authority was highly respected and even feared among the Minangkabau. ${ }^{78}$

Although the cultural variations among the many ethnic groups and societies are vast, women generally enjoyed a relatively high status in most of the societies where female rulers are found. Barbara Watson Andaya, in a comprehensive and critical investigation of women in early modern Southeast Asia, arrived at a "guarded defence" of the claim that women in Southeast Asia generally were less inferior to men than in neighboring regions, including East and South Asia. According to Andaya, this relative gender equality was based on patterns of kinship, location, and marriage as well as on women's economic roles. ${ }^{79}$

${ }^{76}$ Nancy Tanner, "Matrifocality in Indonesia and Africa and Among Black Americans," in Woman, Culture, and Society, Michelle Zimbalist Rosaldo and Louise Lamphere, eds. (Stanford, Calif.: Stanford University Press), I 3 I. See also Peggy Reeves Sanday, Female Power and Male Dominance: On the Origins of Sexual Inequality (Cambridge, U.K.: Cambridge University Press, I98 I ), I I 6f., for a similar definition of the concept.

${ }^{77}$ Derek Nurse and Thomas T. Spear, The Swahili: Reconstructing the History and Language of an African Society, 800-1500 (Philadelphia: University of Pennsylvania Press, I 985), 92; Pouwels, Horn and Crescent, 28; Damir et al., Traditions d'une lingée royales, I6-20; Sophie Blanchy, Maison des femmes, cités des hommes: Filiation, âge et pouvoir à Ngazidja (Comores) (Nanterre: Société d'ethnologie, 20Io).

78 Andaya, Flaming Womb, I67; Sanday, Women at the Center, 32-47; Hans Hägerdal, "Kerajaans Indonesia: An alphabetic enumeration of the former princely states of Indonesia, from the earliest time to the modern period, with simplified genealogies and order of succession," unpubl. ms. (Växjö: Linnaeus University, 2014), r93-95.

79 Andaya, Flaming Womb, 227 f.; see also Veth, "Vrouwenregeeringen." 
Women seem to have enjoyed particularly high status among the Bugis of South Sulawesi, where most of the identified queens regnant in Southeast Asia during the period are found. Although ascribed gender roles existed among the Bugis, they were generally not rigidly defined, and neither sex was seen as intrinsically dominant over the other. Rulers were elected among the members of the ruling family — which was traced bilaterally - and both male and female members were eligible. Filiation on the female side was often preferred, because women, in contrast to men, were prohibited from marrying below their rank and consequently their offspring would be of equal or higher rank than their mother ${ }^{80}$

Bugis female rule was not a simple matter of "descent trumps gender," however. The throne was not inherited according to fixed rules (such as primogeniture); rather, the ruler was elected from among those of royal blood, chiefly on the grounds of personal character and merits. Many of the women who reigned over Bugis kingdoms are described as strong-willed and capable, which probably is a reflection of the meritocratic aspects of this order of succession. Although restricted by descent, the system gave possibilities for able and ambitious individuals, men as well as women, to attain the highest political office. The much greater frequency of male rulers, meanwhile, is probably attributable to the importance attached to typically male traits, such as physical strength and military prowess. ${ }^{81}$

The strict requirement that the ruler be of pure royal blood was a crucial factor for the persistence of female rule among the Bugis, particularly after Islamic influences became more prominent. Gender relations, moreover, continued to be relatively equal among the Bugis even after the adoption of Islam. In that respect, the Bugis were part of a broader pattern in the Indian Ocean World, as the influence of Islam on gender relations and kinship in general took a longer time and was less thorough among non-Arab Muslims living far away from the Islamic heartlands of the Middle East. Women in the Swahili region and the Comoros similarly enjoyed relatively high status in terms of inheritance rights, economic autonomy, marital residence, and public and ritual roles, for example, even after the establishment of Islam in those regions. ${ }^{82}$

${ }^{80}$ Pelras, The Bugis, I6o, I69. According to Thomas Stamford Raffles, women were held in high esteem among the Bugis, as demonstrated, among other things, by the fact that the blood money paid for the murder of a woman was a third higher than that for a man; Thomas Stamford Raffles, The History of Java [18 $\left.\mathrm{I}_{\mathrm{I}}\right]$ ] (Kuala Lumpur: Oxford University Press, 1965), vol. 2, appendix F, clxxix; see also clxxxv.

${ }_{81}$ Caldwell, "Power, State and Society," 408; see also Susan Bolyard Millar, "On Interpreting Gender in Bugis Society," American Ethnologist Io (1983): 477-93; Pelras, The Bugis, I 76.

82 E.g., Pouwels, Horn and Crescent, 28; Askew, "Female Circles"; Caplan, "Gender, Ideology and Modes of Production"; Ottenheimer and Ottenheimer; Historical Dictionary, 
In many places, however, the coming of Islam brought about a shift from matrilineal, or bilateral, recognition of kinship to more strictly patrilineal systems. The shift was most marked among the leading strata of society, particularly ruling families, in the Swahili region. In this context, many sources attest to what may be termed "stranger-kings"whether warriors, merchants, or Islamic teachers-who married indigenous women of the ruling dynasty to found a new, patrilineal dynasty and order of succession. ${ }^{83}$ This process was particularly marked in the Swahili region, where Muslim immigrants identified as "Shirazi" (that is, allegedly but not probably, originating from the Persian town of Shiraz) established new, patrilineal dynasties, from the sixteenth century onward. The shift toward patrilineal kinship and increased male dominance in society, however, was not complete, and some ruling families continued to recognize matrilineal or bilateral descent long after the establishment of Islam. ${ }^{84}$

In some respects, Swahili culture was characterized not so much by a synthesis of Islamic and indigenous traditions as by a superimposition of Islamic laws and practices. Traditional indigenous gender relations and kinship systems continued as part of the traditional mila ideology and practice. ${ }^{85}$ As with the Bugis, who also retained pre-Islamic systems of kinship and inheritance, female rule on the Swahili Coast and in the Comoro Islands continued to be relatively frequent until the eve of colonization-even though the influence of many of the later female (as well as male) rulers seems to have been limited.

\section{Conclusions}

Between the fourteenth and nineteenth centuries a large number of queens regnant, 277 of which have been identified and listed here, are found in the Indian Ocean World, particularly in the western and eastern fringes of the region (the Swahili coast, the Comoro Islands,

90. See also Veth, "Vrouenregeeringen," for a comparative discussion on the Berbers of North Africa and the Malay Archipelago with respect to the position of women.

83 E.g., Nurse and Spear, The Swahili, 92; Ahmed and Harries, The Swahili Chronicle, 84; Middleton, World of the Swahili, 44; Claude Guillot and Ludvik Kalus, Les monuments funéraires et l'historie du Sultanat de Pasai à Sumatra (Paris: Cahiers d'Archipel, 2008), 57-9I. See Marshall Sahlins, Islands of History (Chicago: University of Chicago Press, I985), 73I03, for the general concept.

${ }_{84}$ Damir et al., Traditions d'une lingée royales, I 5-20; Nurse and Spear, The Swahili, $76-$ 78; Berger and White, Women in Sub-Saharan Africa, I 9.

${ }_{85}$ Caplan, "Gender, Ideology and Modes of Production"; see also Askew, "Female Circles," 74 f. 
Madagascar, and the Malay Archipelago). To a large extent, the queens are found in areas dominated or influenced by Austronesian speaking peoples. Most of them ruled over relatively small kingdoms or chiefdoms, many of which were heavily involved in long-distance commercial networks. By contrast, few queens regnant are found on the northern shores of the Indian Ocean or as rulers over large or complex, in institutional terms, states.

Most of the queens were presumably Muslims ruling over reputedly Muslim societies, and about a tenth appear to have been Christians, mainly in Timor. The relative frequency of Muslim queens regnant in parts of the Indian Ocean World contrasts sharply with the predominantly Muslim region of Southwest Asia and North Africa, where no women seem to have exercised formal political sovereignty during the period under study. The societies over which the women ruled, however, are generally not described in contemporary sources as giving a prominent position to Islamic law and practices. With few exceptionsmainly in seventeenth century Aceh-most of the queens for whom information is available do not seem to have based their legitimacy to any great extent on religion. On the contrary: Islam was at times used as a basis for opposition against female rule, and the spread of Islam was in many places accompanied by the adoption, or superimposition, of patrilineal kinship systems as well as a more pronounced male dominance in general, both of which seem to have caused a decline in the frequency of queens regnant as well as in their influence. In some parts of the region, however, such as among the Bugis of South Sulawesi, in Timor, Madagascar, and the Comoro Islands, female rule continued to be relatively frequent in spite of the advances of world religions, particularly Islam and Christianity.

Female rule may have become more common in the nineteenth century up until the advent or consolidation of European colonization, although this impression may largely be due to the richer sources. In the end, however, the intensified European expansion brought about a decline in female political authority as indigenous states were incorporated in colonial empires. Not only did colonization bring about the end of autonomous political power, thereby effectively ending the long-standing acceptance for female sovereignty. Since colonial governments and administrations were heavily male-dominated, to the extent that indigenous societies were able to preserve some autonomy, female rule also declined because the colonial state tended to deal with and thus favor male leaders.

Previous research has suggested that female rule-particularly in commercially oriented city-states in Southeast Asia-was preferred by 
influential commercial elites because it was seen as peaceful, businesslike, and benevolent in contrast to the belligerence, arbitrariness, and despotism of absolutist male rulers. The argument, however, seems to be tangential and is not supported in the contemporary sources. In the trading states of both the Swahili region and maritime Southeast Asia, the authority of the sovereign, regardless of whether it was a man or a woman, was generally relatively weak, and his or her main task was to promote commerce and maintain security. With regard to the former task, gender probably did not matter greatly, but with regard to the latter, having a female ruler implied military weakness and was associated with greater risk of foreign aggression and intrusions.

On a general level, the explanation for the relative frequency of female sovereignty in the Indian Ocean World lies in a combination of two factors: the need to preserve political stability and the matrifocal orientation of many societies in the Indian Ocean World. With regard to the first factor, the Indian Ocean World resembles Europe during the same period. In many, if not most, states in both regions, female rule was accepted as a last resort when there was no eligible male heir to the throne. Allowing a woman to accede to the throne in such extraordinary-but not unusual-circumstances gave a greater flexibility and stability to the political system and provided the essential means to avoid a dynastic crisis and the associated risk of political upheaval and civil war.

A second condition for the relative prevalence of female rulers in the Indian Ocean World from the fourteenth to the nineteenth century was the matrifocal orientation of many societies in the region. Although there are considerable variations over time and among different societies and cultures, women generally enjoyed a relatively high degree of autonomy and status in both Southeast Asia and along the east coast of Africa, including the Swahili Coast, the Comoro Islands and Madagascar. Women could in most places own and inherit property, and they often played prominent roles in public and ritual life. As in Europe, descent was seen as more important than sex in matters of dynastic succession, but since women for the most part were not seen as intrinsically deficient or less capable than men-in contrast to the misogyny evident in most of the dominating religious and ideological systems of mainland Eurasia at the time-female sovereignty was less of an anathema in the Indian Ocean World. Female rule could thus frequently be accepted with relative ease-although it rarely seems to have been the preferred solution. 


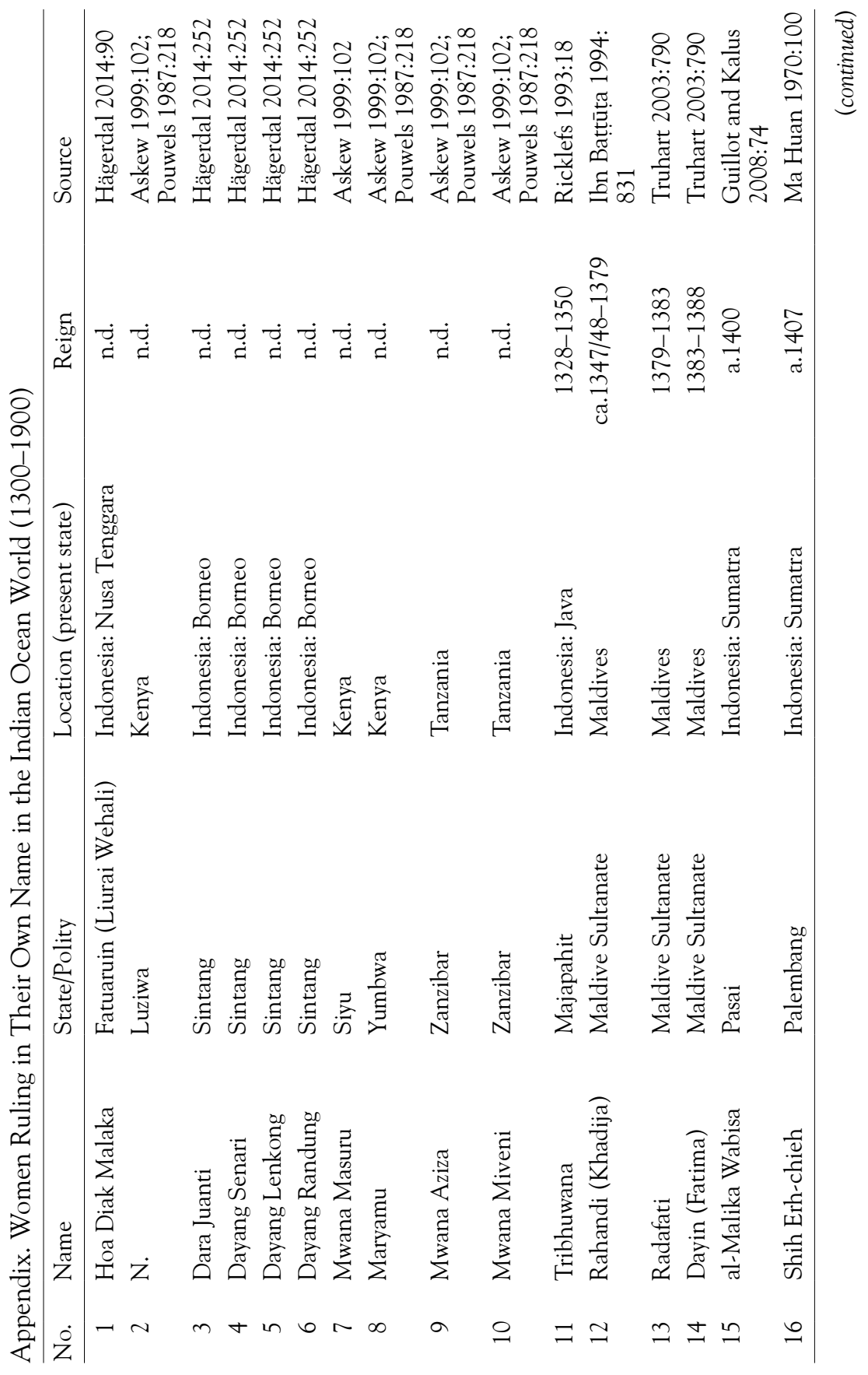




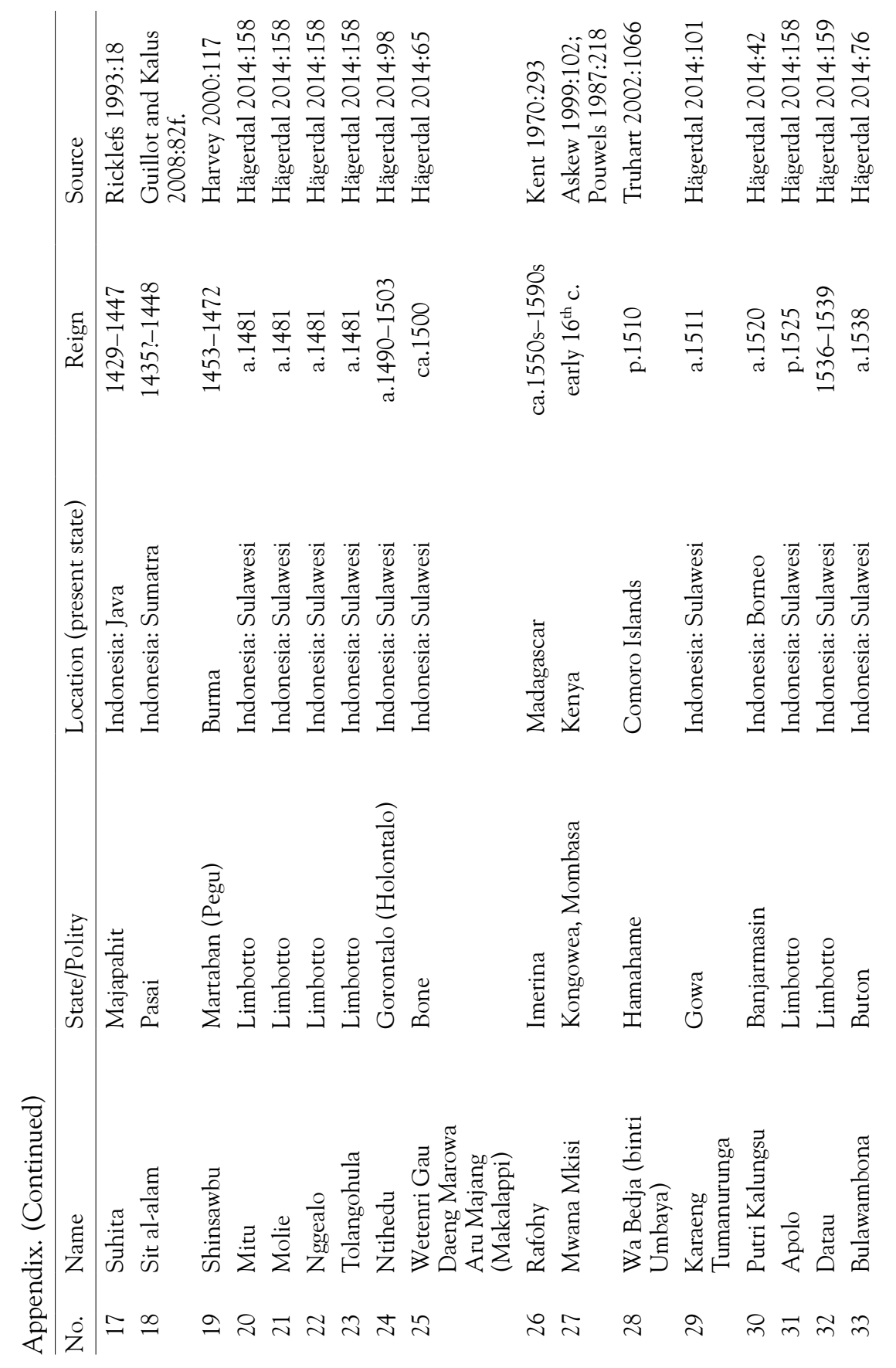




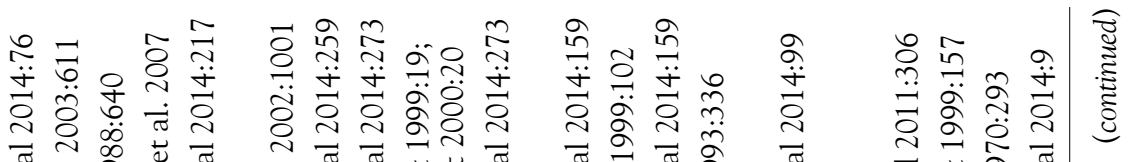

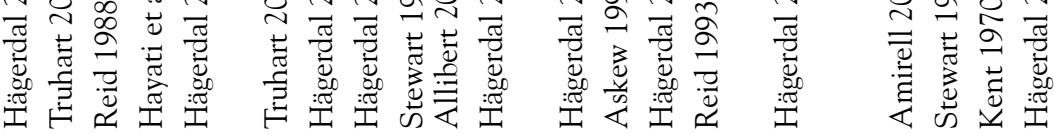

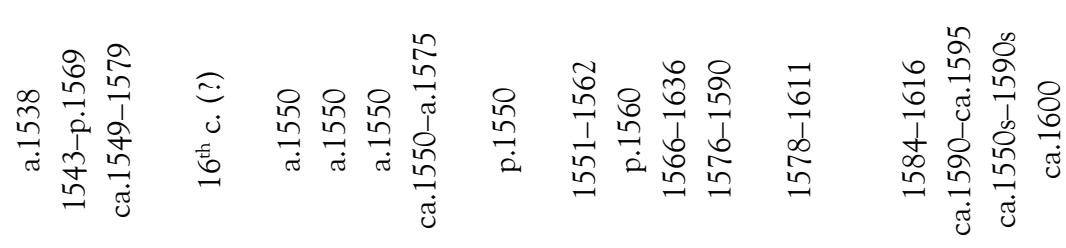

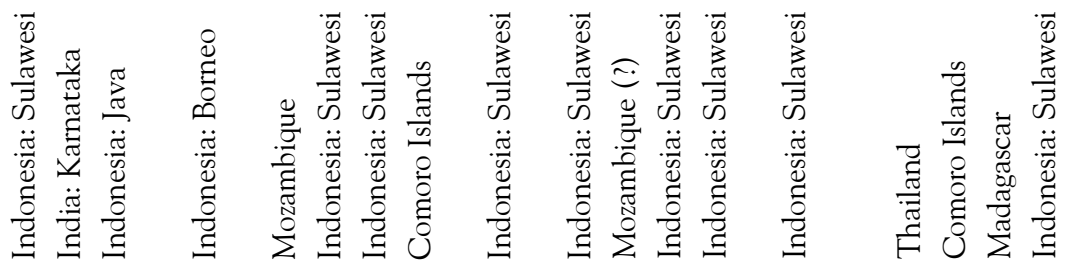

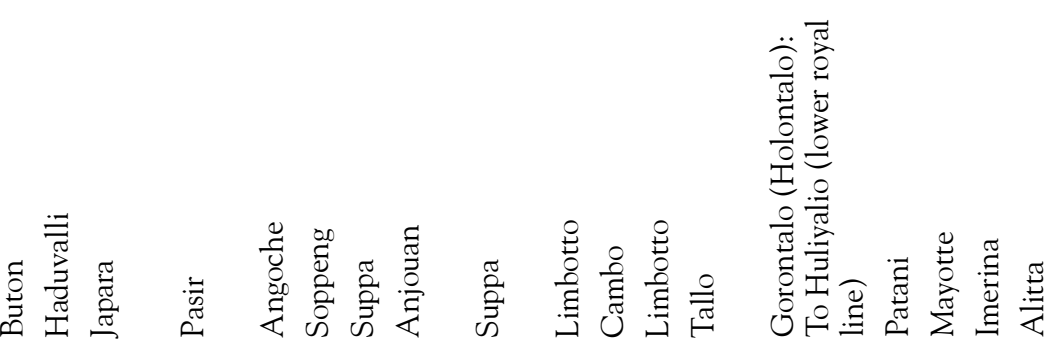

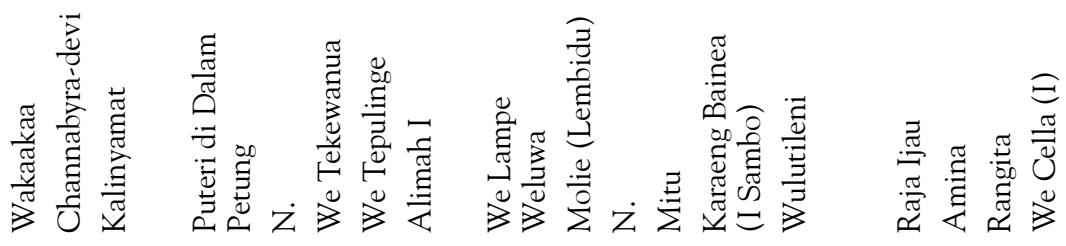

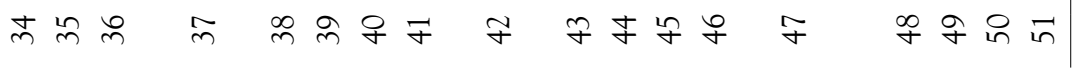




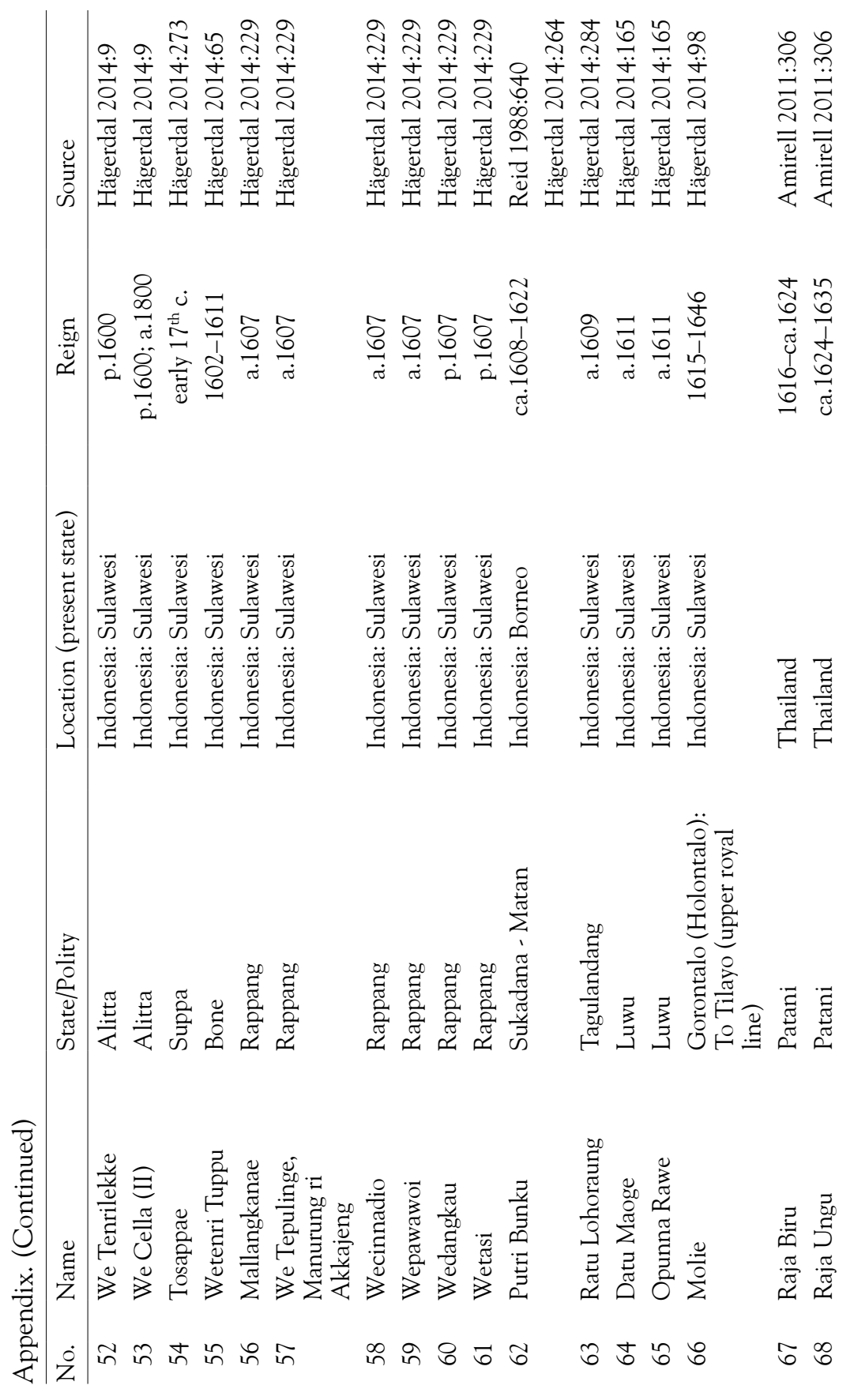




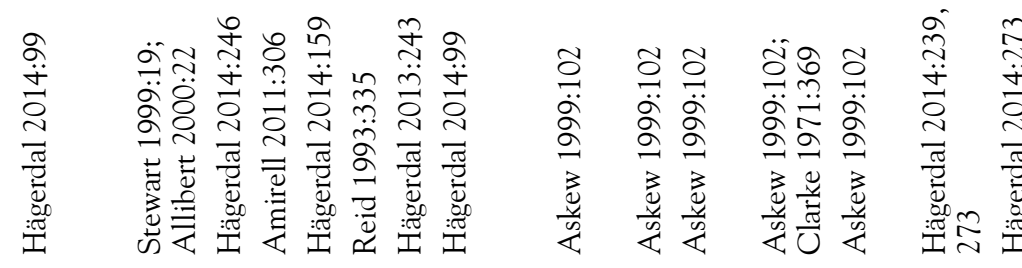

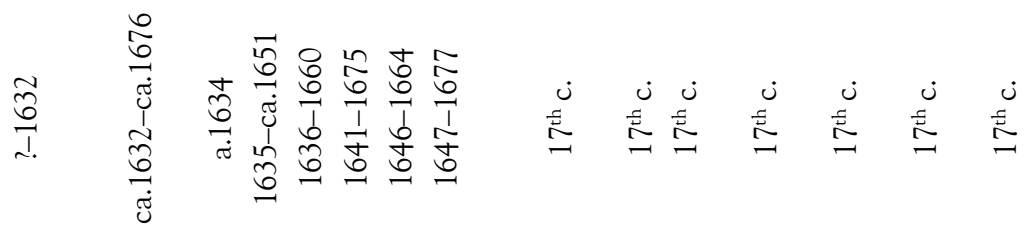
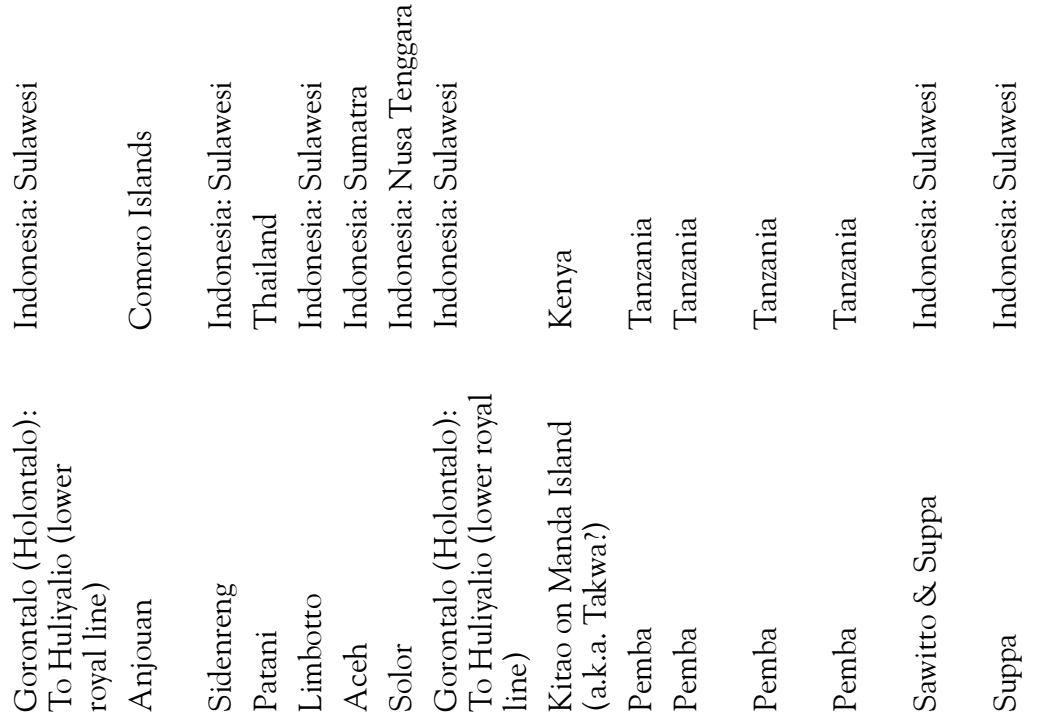

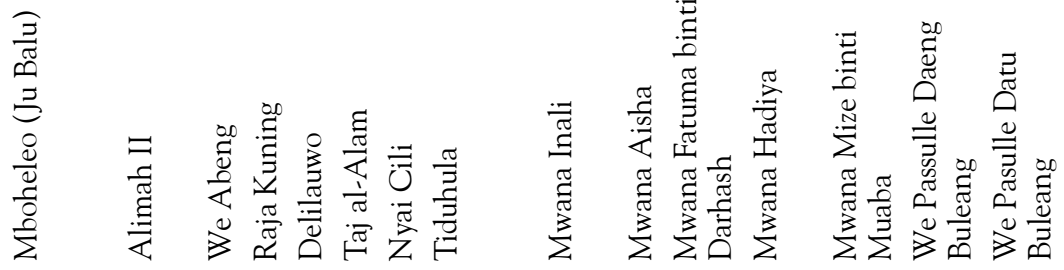

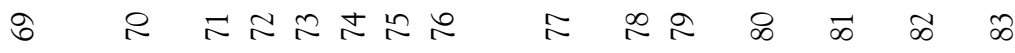




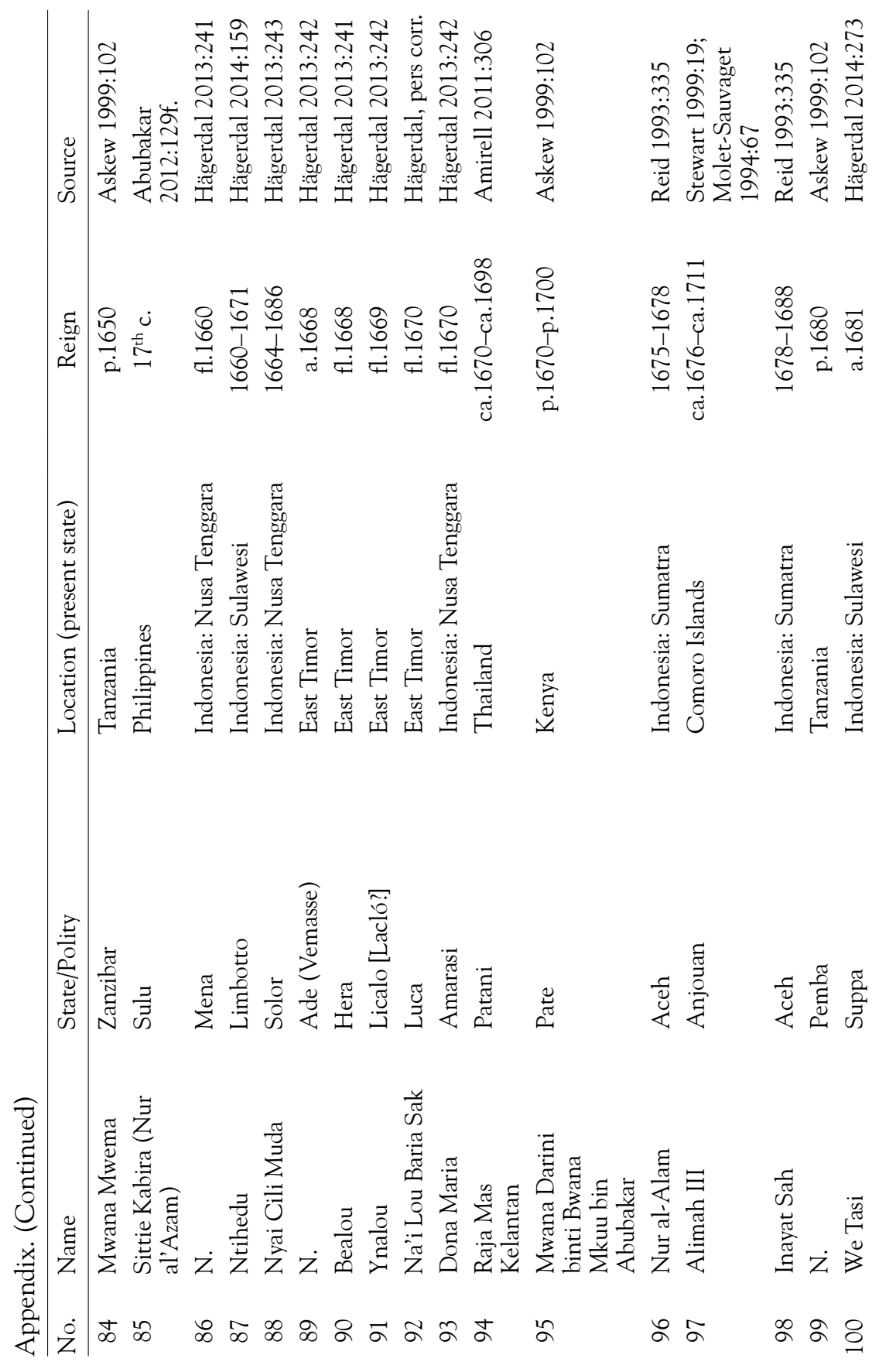




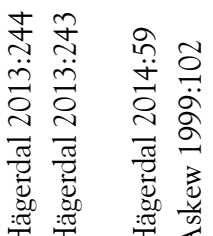

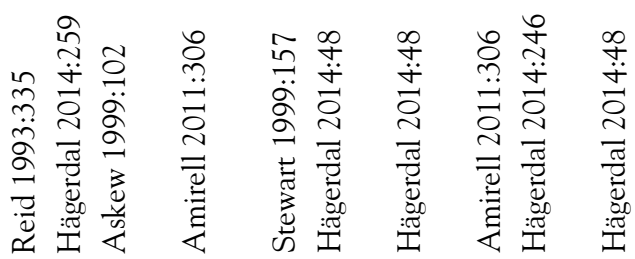

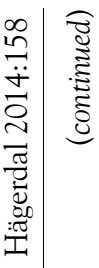

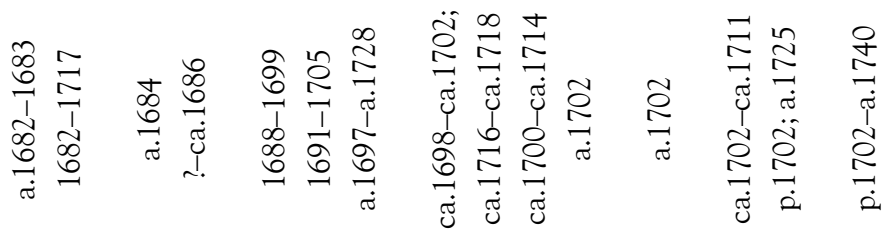

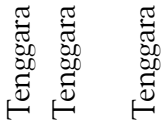

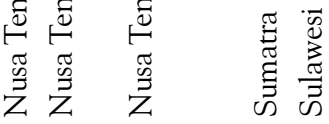

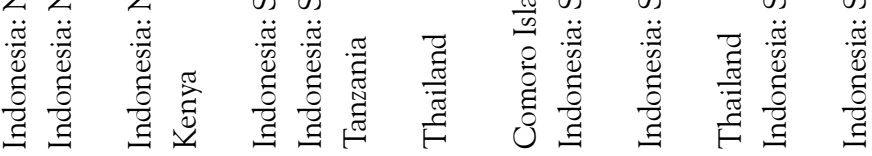

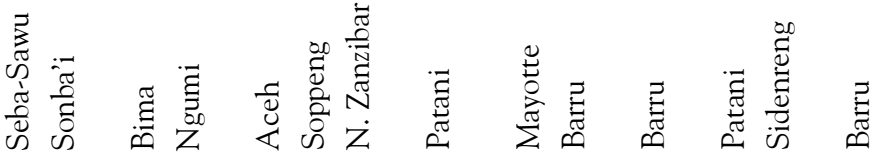

$\stackrel{\Xi}{\oplus}$

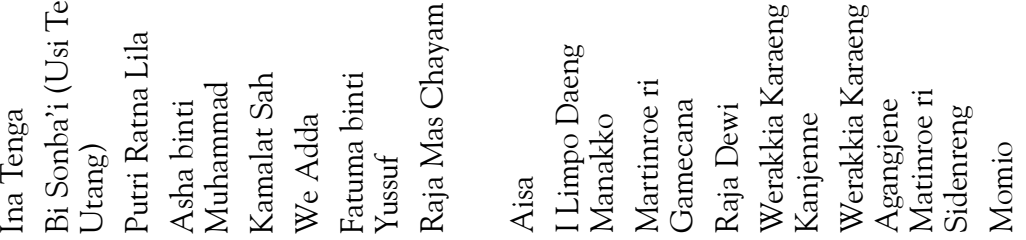

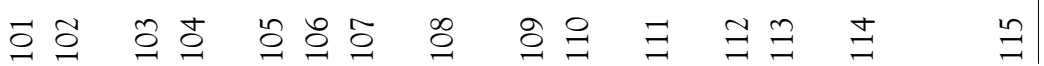




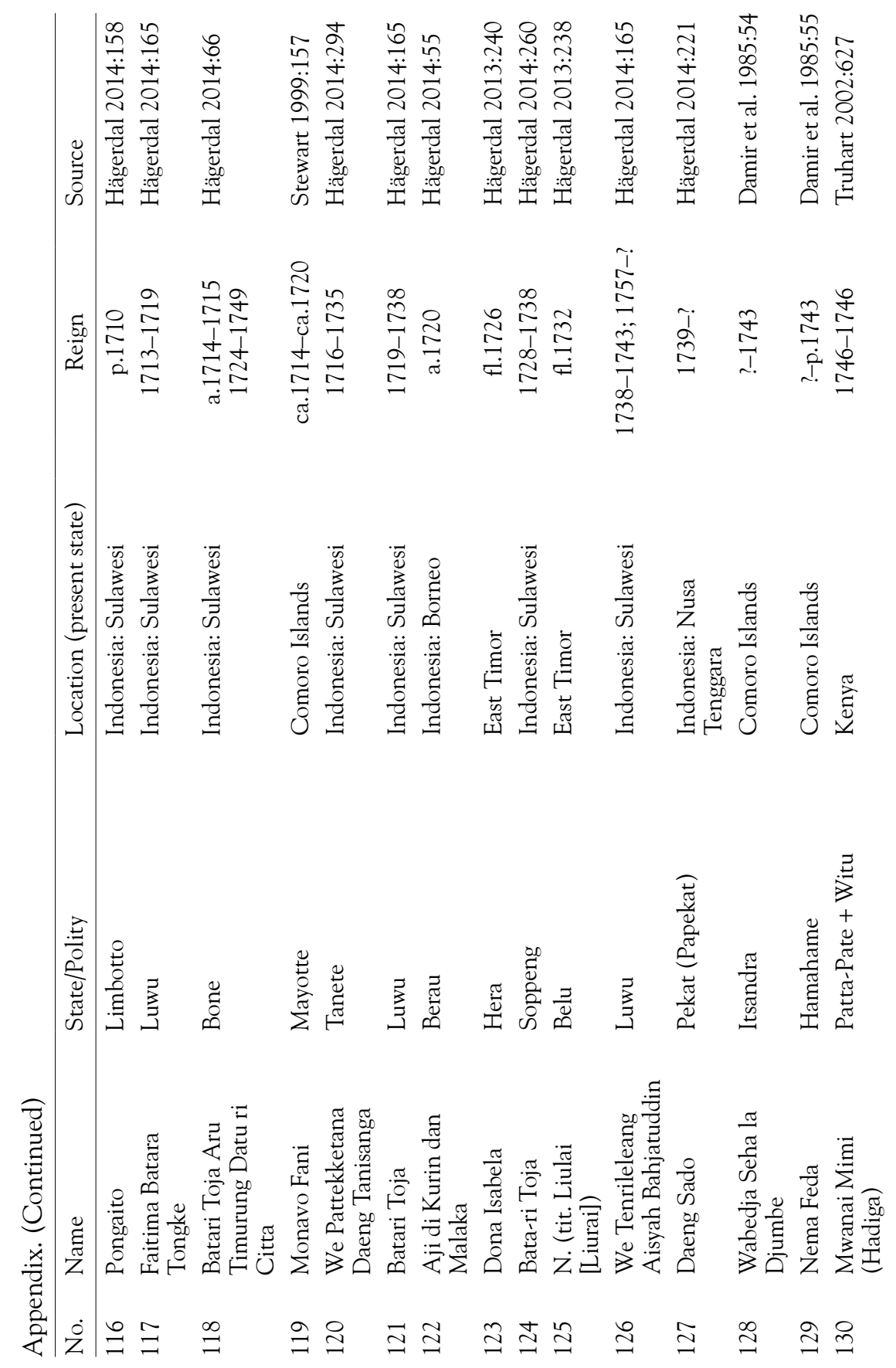




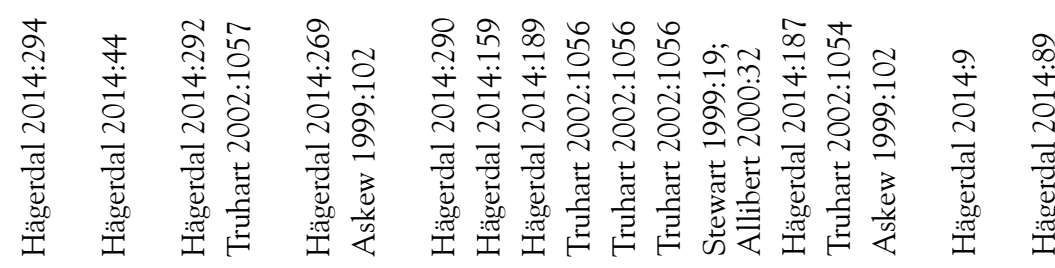

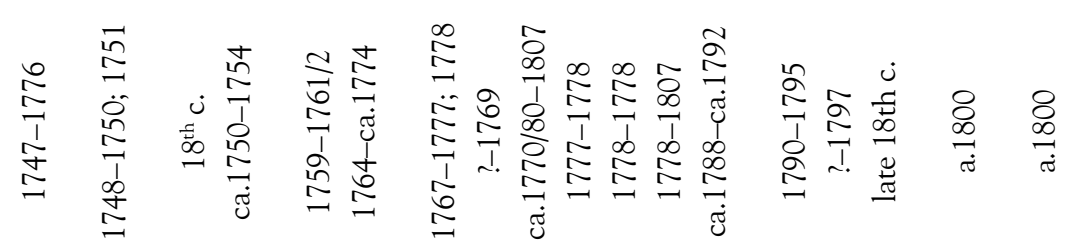

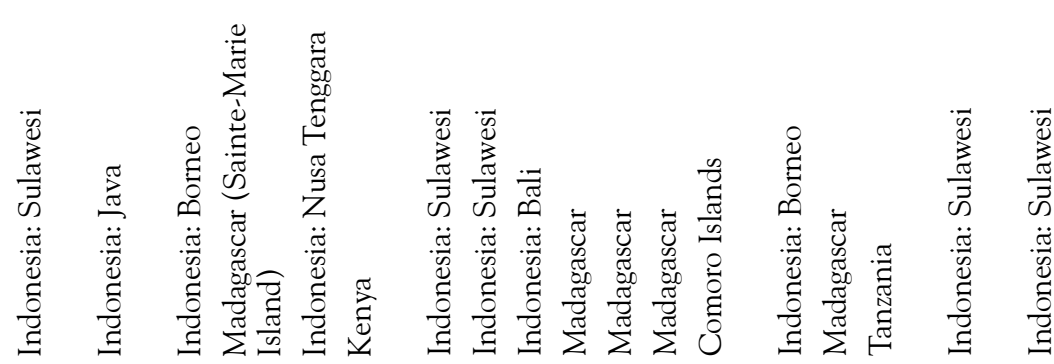

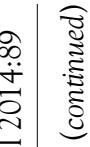




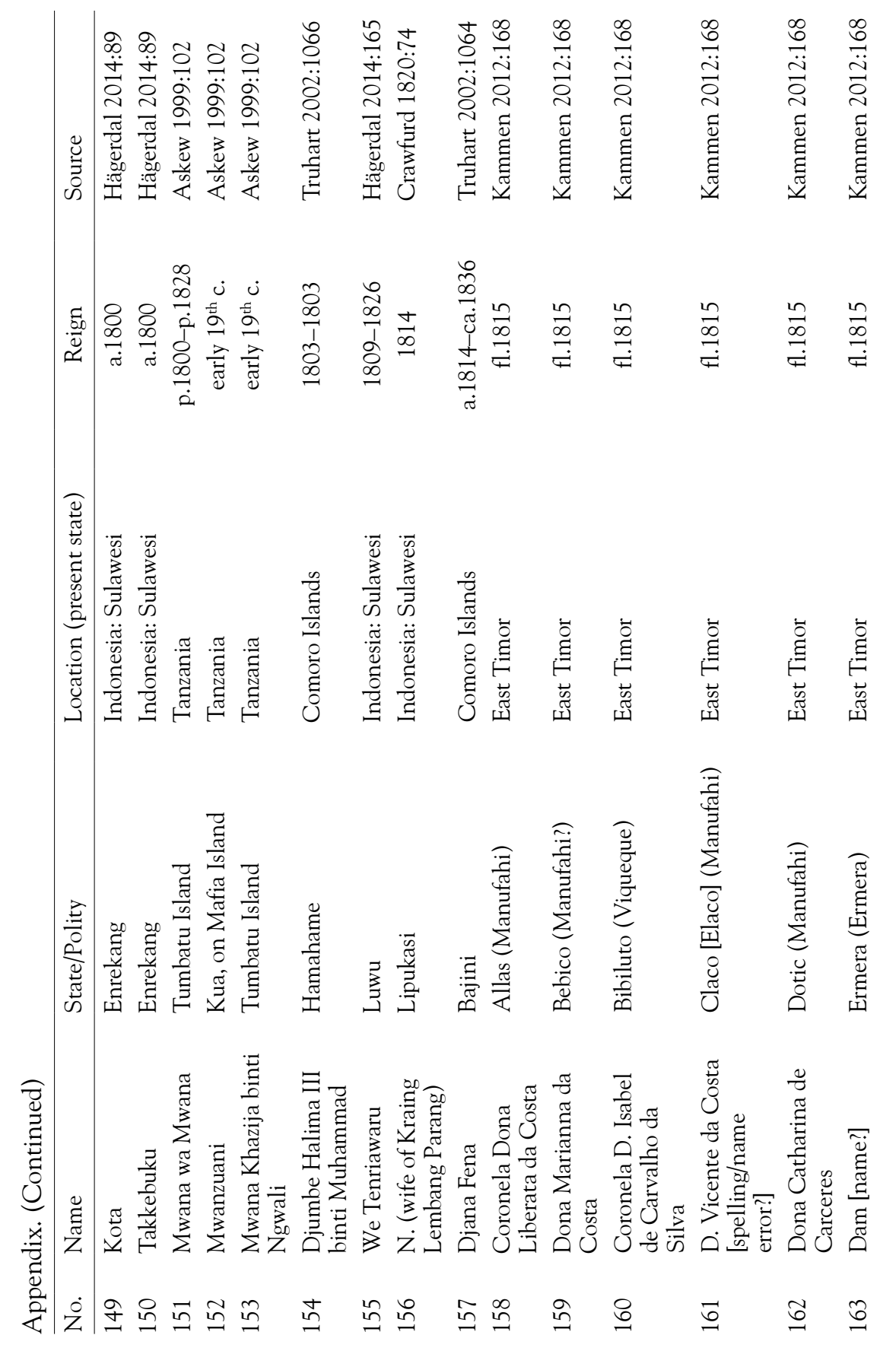




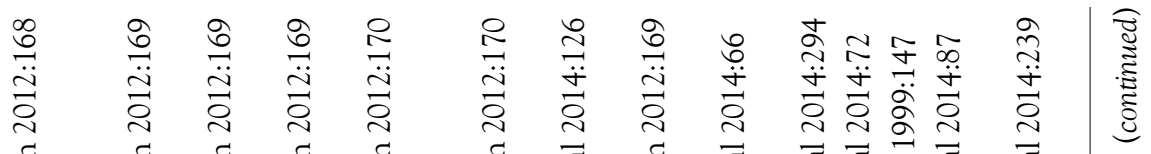

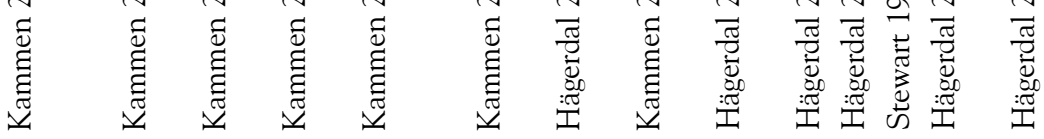

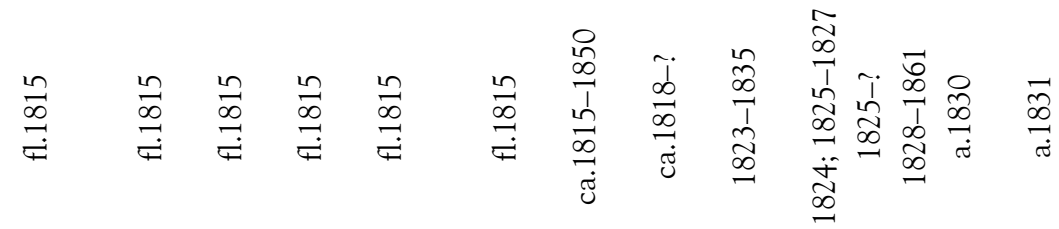

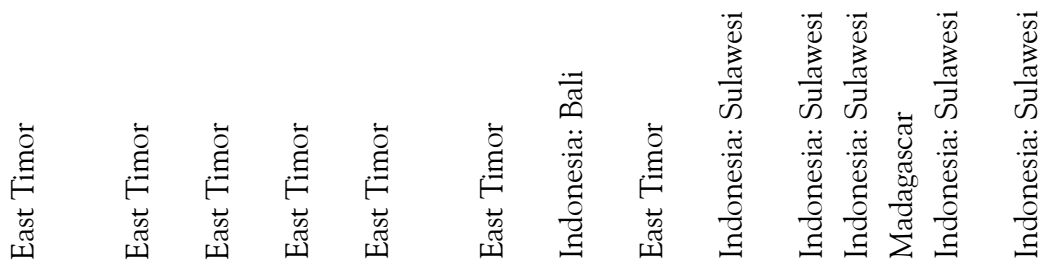

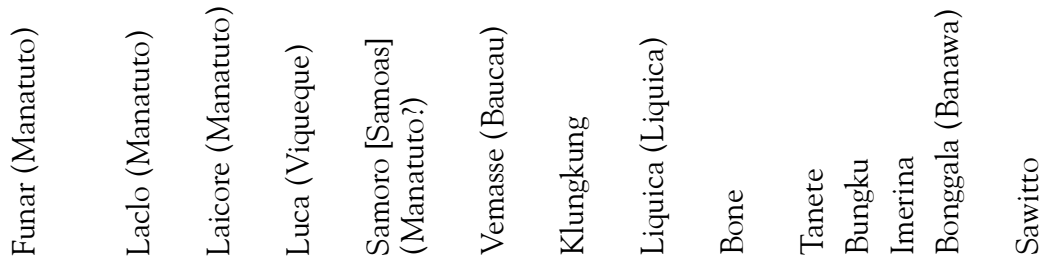

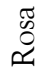

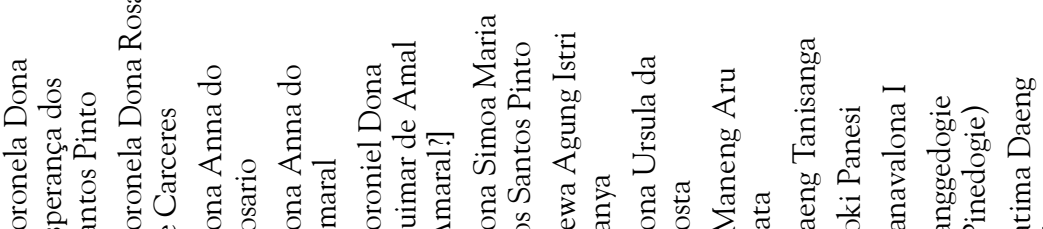

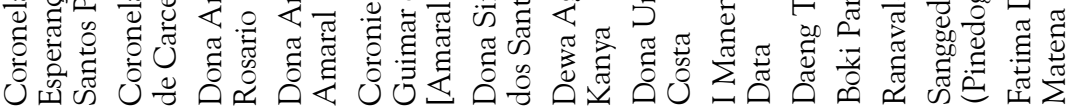

ఫ) 


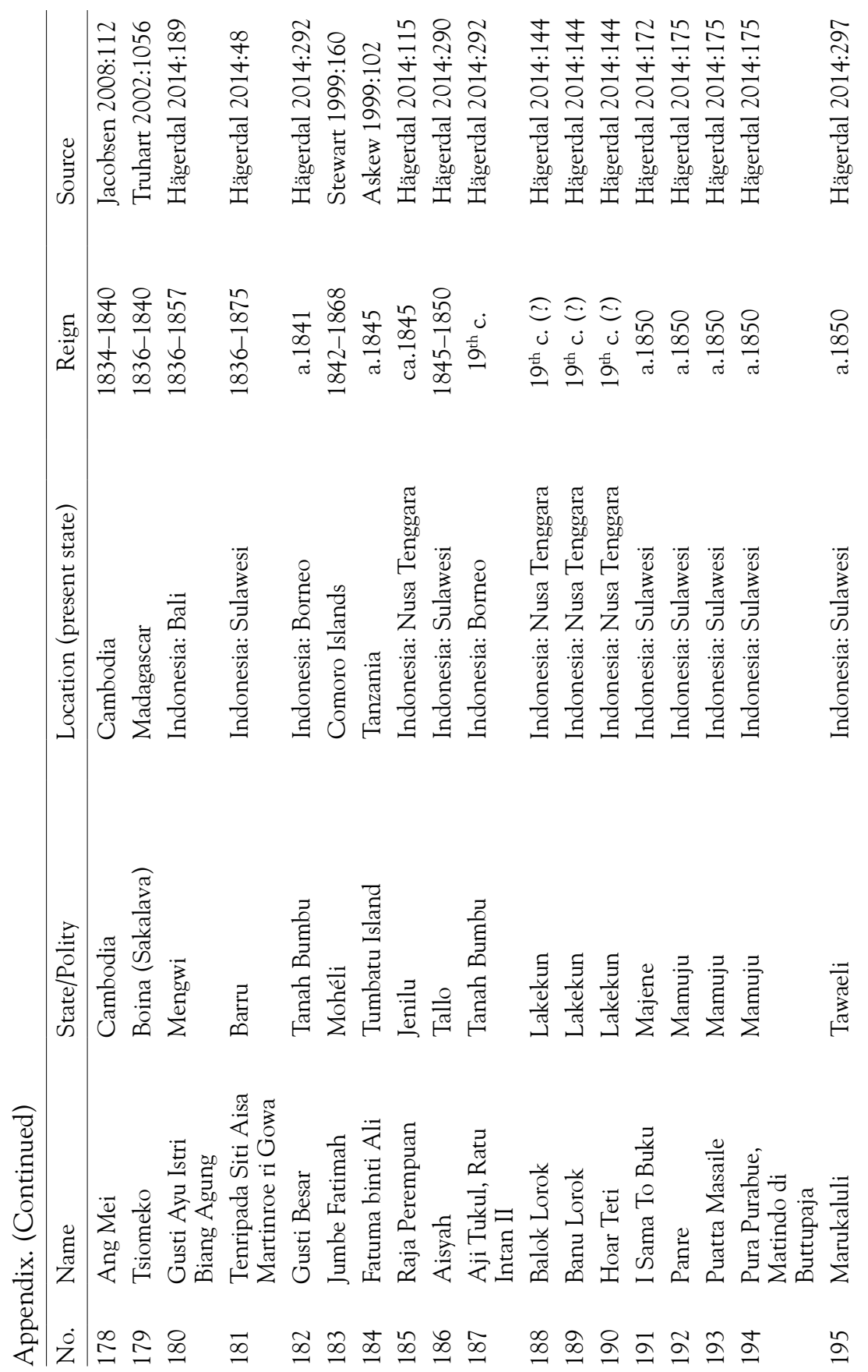




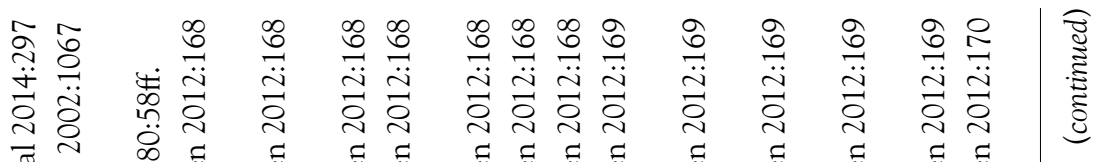

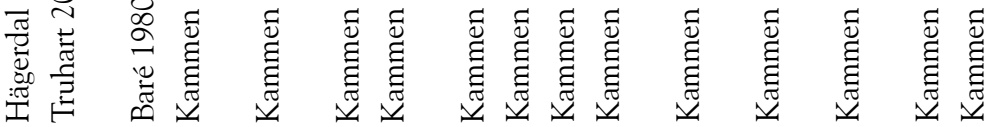

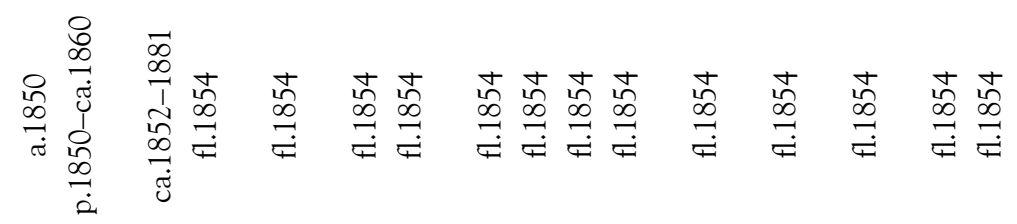

章基

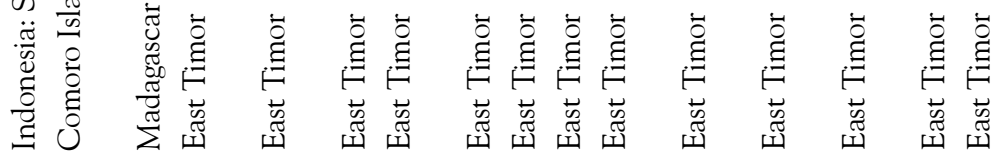

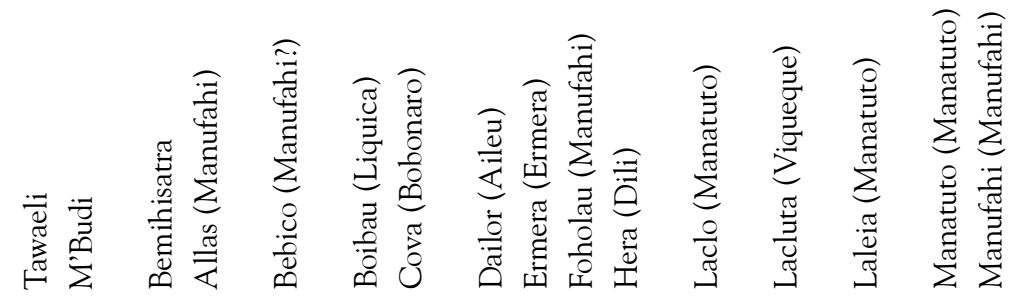

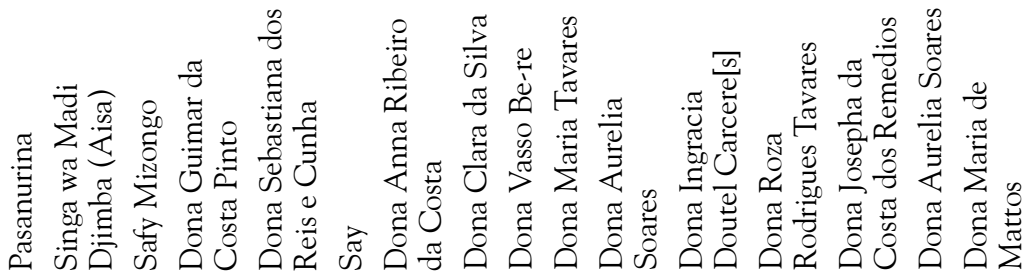

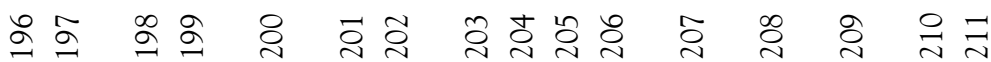




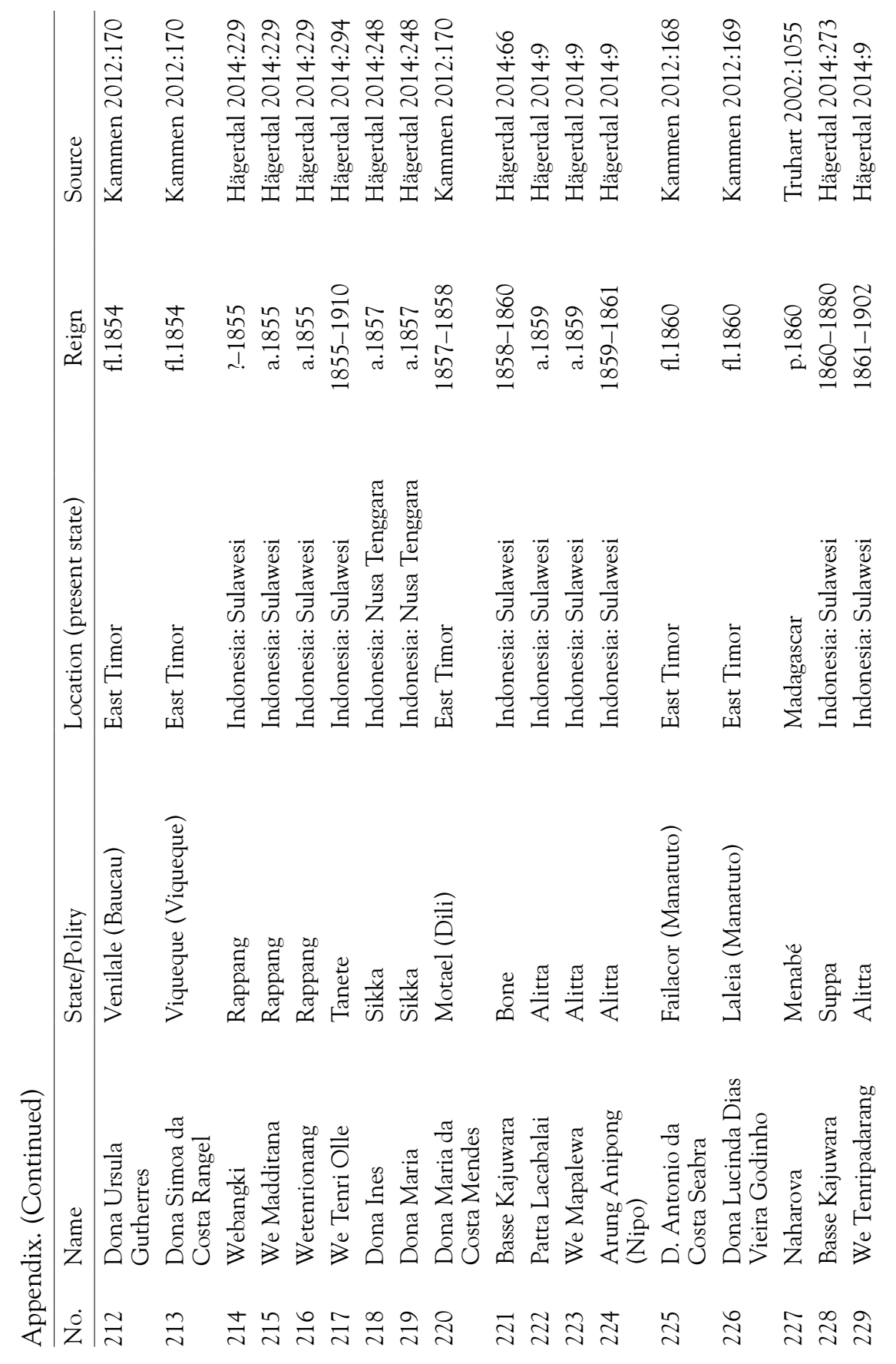




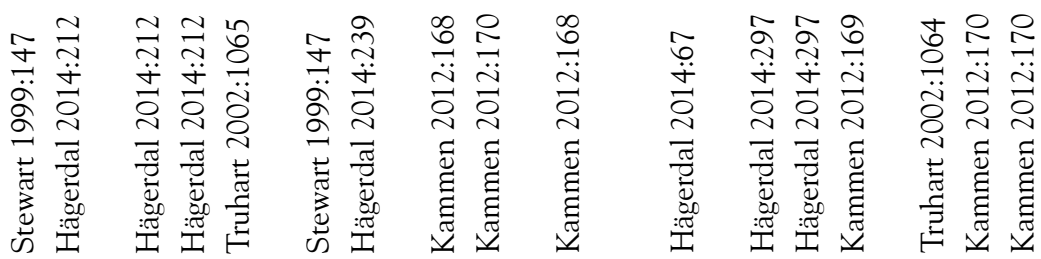

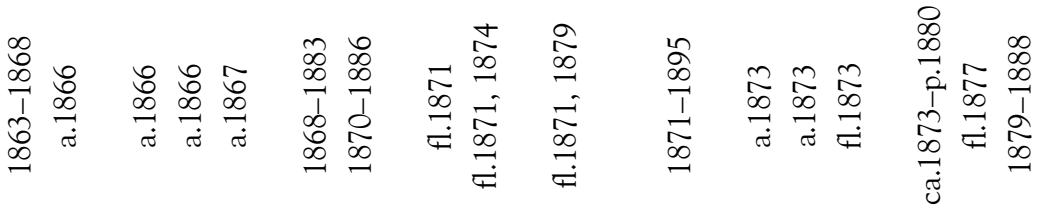

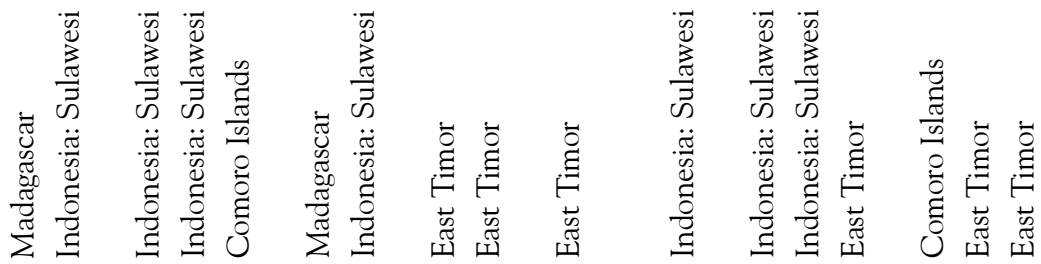

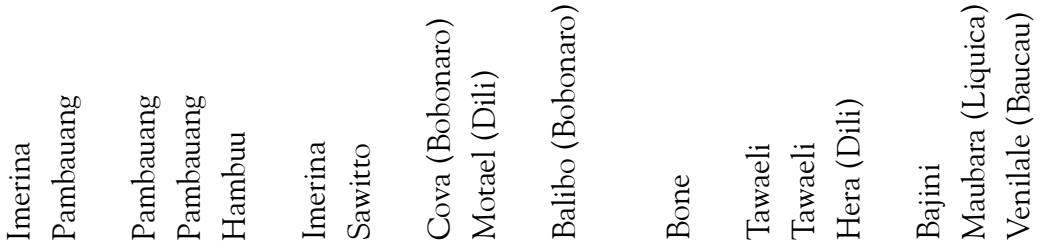

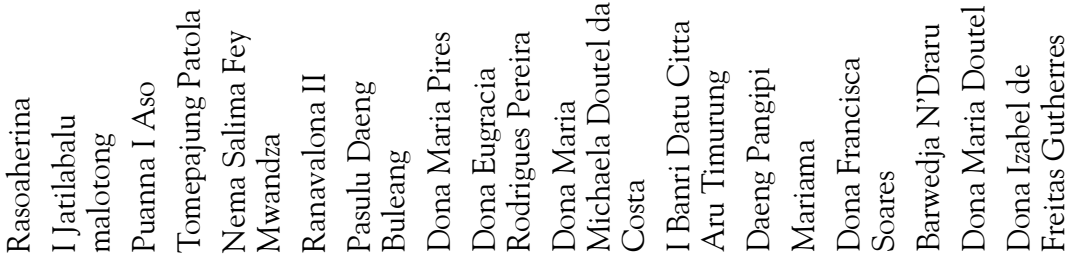

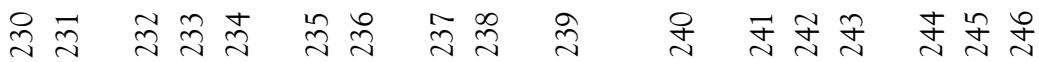




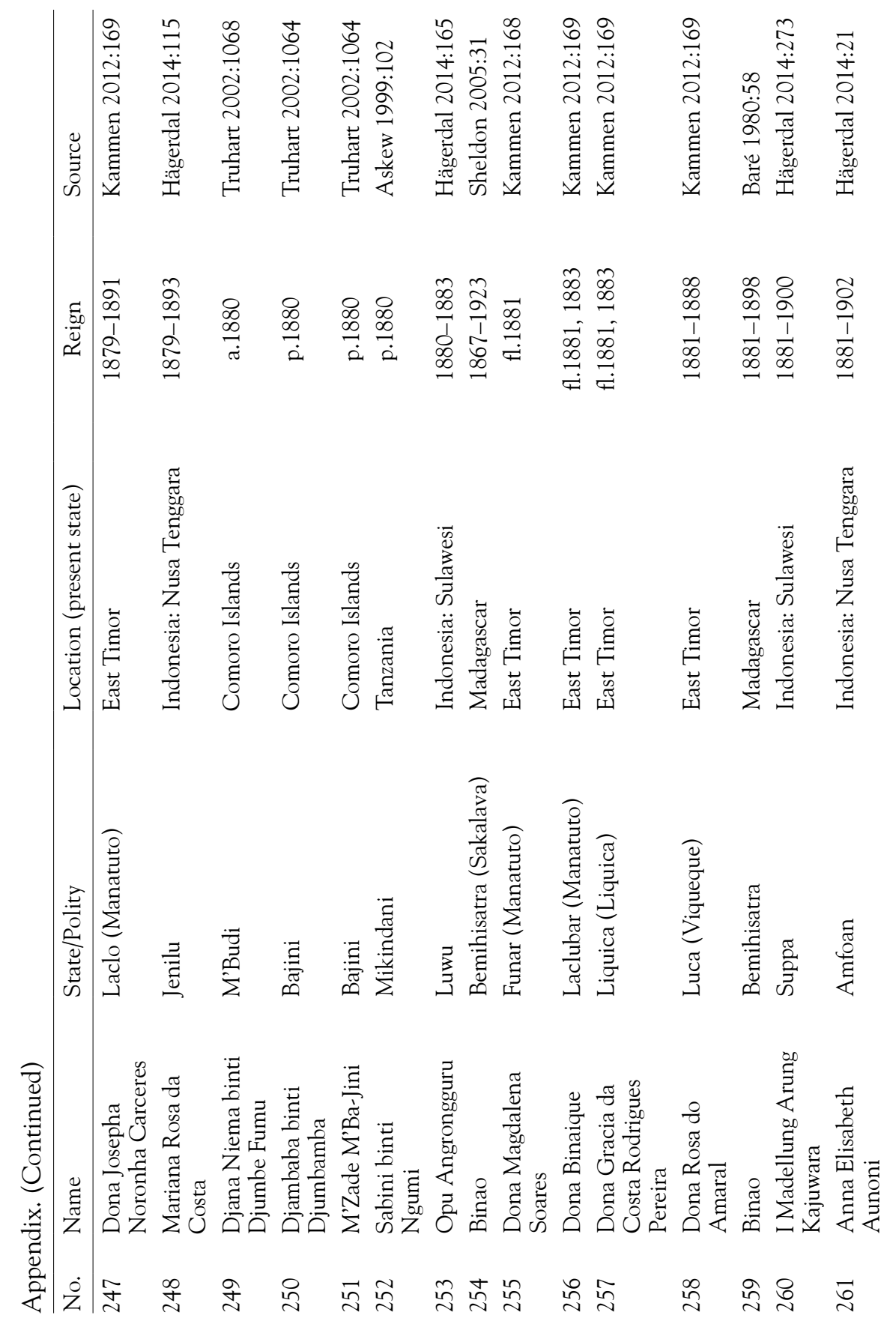




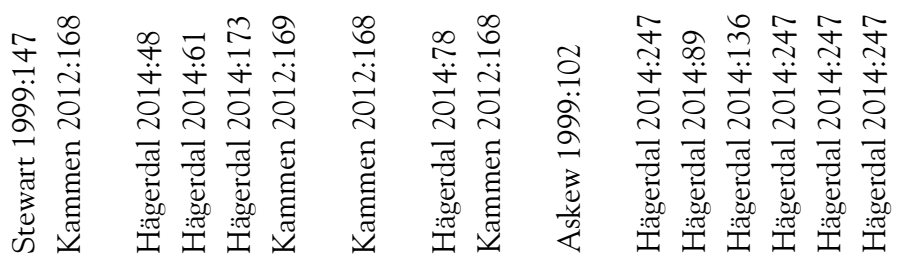

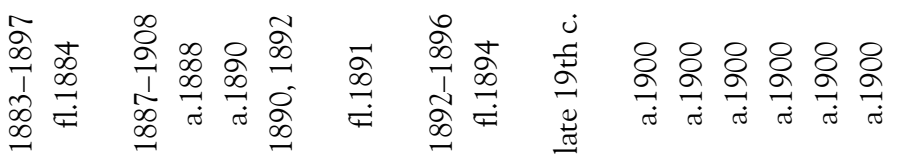

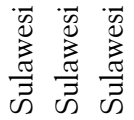

$\frac{\vec{d}}{\overrightarrow{0}}$

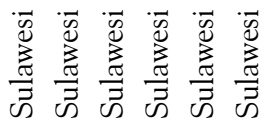

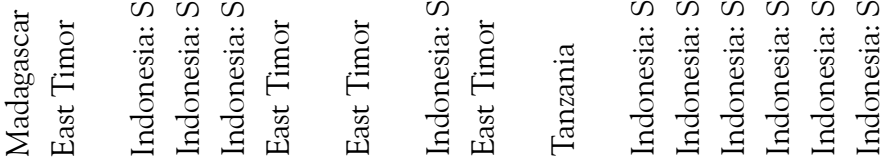

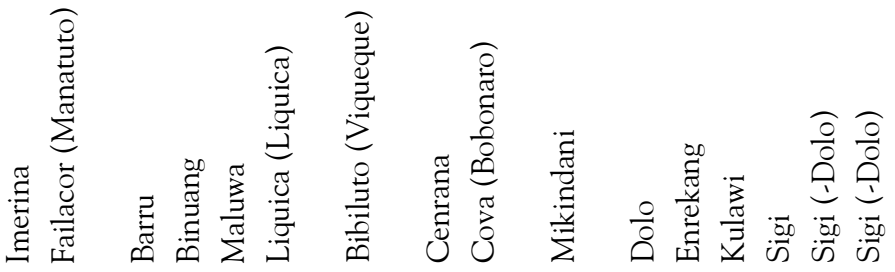

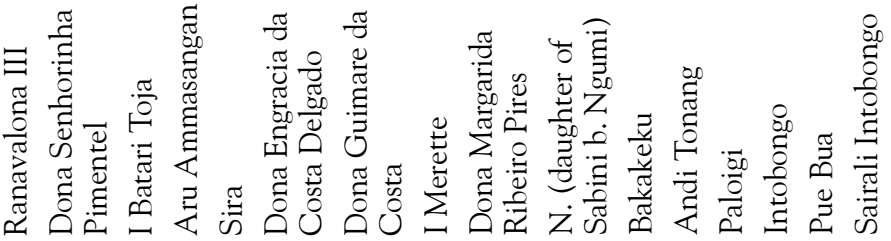

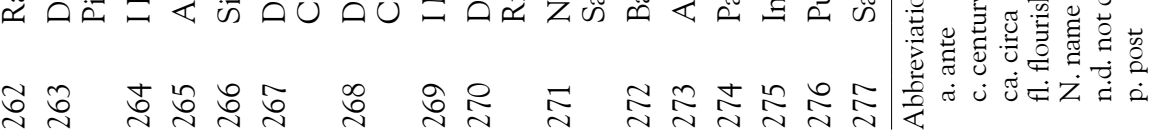




\section{REFERENCES}

Abubakar, Carmen A. 2012. "Wither the Roses of Yesteryears: An Exploratory Look into the Lives of Moro Women during the Colonial Period." Review of Women's Studies 8, 119-32.

Allibert, Claude. 2000. "La chronique d'Anjouan par Said Ahmed Zaki (ancien cadi d'Anjouan)." Études océan Indien 29:9-92.

Amirell, Stefan. 2011. "The Blessings and Perils of Female Rule: New Perspectives on the Reigning Queens of Patani, ca. 1584-1718." Journal of Southeast Asian Studies 42, no. 2, 303-23.

Askew, Kelly M. 1999. "Female Circles and Male Lines: Gender Dynamics along the Swahili Coast." Africa Today 46, nos. 3-4, 67-102.

Baré, Jean François. 1980. Sable rouge: Une monarchie du nord-ouest malgache dans l'histoire. Paris: l'Harmattan.

Clarke, John Henrik. 1971. "Time of Trouble." In The Horizon History of Africa, edited by Alvin M. Josephy Jr. New York: American Heritage.

Crawfurd, John. 1820. History of the Indian archipelago: Containing an account of the manners, arts, languages, religions, institutions, and commerce of its inhabitants, vol. 1. Edinburgh: Archibald Constable.

Damir, B. A., G. Boulinier, and P. Ottino. 1985. Traditions d'une lingée royales des Comores. Paris: l'Harmattan.

Guillot, Claude, and Ludvik Kalus. 2008. Les monuments funéraires et l'histoire du sultanat de Pasai à Sumatra (XIIIe-XVIe siècles). Paris: Éditions de la Maison des Sciences de l'Homme.

Hägerdal, Hans. 2013. "Cycles of Queenship on Timor: A Response to Douglas Kammen." Archipel 85:237-51.

. 2014. "Kerajaan2 Indonesia: An alphabetic enumeration of the former princely states of Indonesia, from the earliest time to the modern period, with simplified genealogies and order of succession." Unpubl. ms. Växjö: Linnaeus University.

Harvey, Godfrey Eric. 2000 (1925). History of Burma. New Dehli: Asian Educational Services.

Hayati, Chusnul, Agustinus Supriyono, Sugiyarto, Siti Maziyah, Mulyo Hadi Purnomo, and Alamsyah. 2007. Ratu Kalinyamat: Biografi tokoh wanita abad XVI dari Jepara. Semarang: Penerbit Jeda.

Ibn Battūța. 1994 (1355). The Travels of Ibn Battututa A.D. 1325-1354, vol. 4, edited by H. A. R. Gibb. London: The Hakluyt Society.

Jacobsen, Trudy. 2008. Lost Goddesses: The Denial of Female Power in Cambodian History. Copenhagen: NIAS Press.

Kammen, Douglas. 2012. "Queens of Timor." Archipel 84:149-73.

Kent, Raymond K. 1970. Early Kingdoms in Madagascar 1500-1700. New York: Holt, Rinehart and Winston.

Ma Huan. 1970. Ying-yai Sheng-lan: The Overall Survey of the Ocean's Shores, 1433. Cambridge, U.K.: Cambridge University Press for the Hakluyt Society. 
Molet-Sauvaget, Anne, ed. 1994. Documents anciens sur les îles Comores (1591-1810). Paris: Institut des Langues et Civilisations Orientales.

Pouwels, Randall L. 1987. Horn and Crescent: Cultural Change and Traditional Islam on the East African Coast, 800-1900. Cambridge, U.K.: Cambridge University Press.

Reid, Anthony. 1988. "Female Roles in Pre-Colonial Southeast Asia." Modern Asian Studies 22, no. 3, 629-45.

.1993. Southeast Asia in the Age of Commerce 1450-1680: Volume Two: Expansion and Crisis. New Haven, Conn.: Yale University Press.

Ricklefs, M. C. 1993. A History of Modern Indonesia since c. 1300. 2nd ed. Stanford, Calif.: Stanford University Press.

Sheldon, Kathleen. 2005. Historical Dictionary of Women in Sub-Saharan Africa. Lanham, Md.: Scarecrow Press.

Stewart, John. 1999. African States and Rulers. Jefferson, N.C.: McFarland.

Truhart, Peter. 2002. Regents of Nations: Systematic Chronology of States and Their Political Representatives in Past and Present: A Biographical Reference Book. Part 2: America and Africa. Munich: K. G. Saur. 2003. Regents of Nations: Systematic Chronology of States and Their Political Representatives in Past and Present: A Biographical Reference Book. Part 3: Asia and Pacific Oceania. Munich: K. G. Saur. 